\title{
Evaluation of ACCMIP outgoing longwave radiation from tropospheric ozone using TES satellite observations
}

K. W. Bowman ${ }^{1}$, D. T. Shindell ${ }^{2}$, H. M. Worden ${ }^{3}$, J.F. Lamarque ${ }^{3}$, P. J. Young ${ }^{4}$, D. S. Stevenson ${ }^{5}$, Z. Qu ${ }^{6}$, M. de la Torre ${ }^{1}$, D. Bergmann ${ }^{7}$, P. J. Cameron-Smith ${ }^{7}$, W. J. Collinss ${ }^{8}$, R. Doherty ${ }^{5}$, S. B. Dalsøren ${ }^{9}$, G. Faluvegi ${ }^{2}$, G. Folberth ${ }^{10}$, L. W. Horowitz ${ }^{11}$, B. M. Josse ${ }^{12}$, Y. H. Lee ${ }^{2}$, I. A. MacKenzie ${ }^{5}$, G. Myhre ${ }^{9}$, T. Nagashima ${ }^{13}$, V. Naik ${ }^{15}$, D. A. Plummer ${ }^{16}$, S. T. Rumbold ${ }^{10}$, R. B. Skeie ${ }^{9}$, S. A. Strode $^{17}$, K. Sudo ${ }^{14}$, S. Szopa ${ }^{18}$, A. Voulgarakis ${ }^{20}$, G. Zeng ${ }^{19}$, S. S. Kulawik ${ }^{1}$, A. M. Aghedo ${ }^{21}$, and J. R. Worden ${ }^{1}$

${ }^{1}$ Jet Propulsion Laboratory-California Institute of Technology, Pasadena, CA, USA

${ }^{2}$ NASA Goddard Institute for Space Studies and Columbia Earth Institute, New York, NY, USA

${ }^{3}$ National Center for Atmospheric Research,Boulder, Colorado, USA

${ }^{4}$ Lancaster Environment Centre, Lancaster University, Lancaster, UK

${ }^{5}$ School of GeoSciences, The University of Edinburgh, Edinburgh, UK

${ }^{6}$ Raytheon Intelligence \& Information Systems, Pasadena, CA USA

${ }^{7}$ Lawrence Livermore National Laboratory, Livermore, CA, USA

${ }^{8}$ Department of Meteorology, University of Reading, Reading, UK

${ }^{9}$ Center for International Climate and Environmental Research, Oslo, Norway

${ }^{10}$ Met Office, Hadley Centre, Exeter, UK

${ }^{11}$ NOAA Geophysical Fluid Dynamics Laboratory, Princeton, NJ, USA

${ }^{12}$ GAME/CNRM, Météo-France, CNRS - Centre National de Recherches Météorologiques, Toulouse, France

${ }^{13}$ National Institute for Environmental Studies, Tsukuba, Japan

${ }^{14}$ Graduate School of Environmental Studies, Nagoya University, Nagoya, Japan

${ }^{15}$ UCAR/NOAA Geophysical Fluid Dynamics Laboratory, Princeton, NJ, USA

${ }^{16}$ Canadian Centre for Climate Modeling and Analysis, Environment Canada, Victoria, British Columbia, Canada

${ }^{17}$ NASA Goddard Space Flight Center and Universities Space Research Association, Columbia, Maryland, USA

${ }^{18}$ Laboratoire des Sciences du Climat et l'Environnement, Gif-sur-Yvette, France

${ }^{19}$ National Institute of Water and Atmospheric Research, Lauder, New Zealand

${ }^{20}$ Department of Physics, Imperial College London, London, UK

${ }^{21}$ Civil and Environmental Engineering, Rice University, Houston, TX, USA

Correspondence to: K. W. Bowman (kevin.bowman@jpl.nasa.gov)

Received: 31 July 2012 - Published in Atmos. Chem. Phys. Discuss.: 11 September 2012

Revised: 5 March 2013 - Accepted: 14 March 2013 - Published: 18 April 2013

\begin{abstract}
We use simultaneous observations of tropospheric ozone and outgoing longwave radiation (OLR) sensitivity to tropospheric ozone from the Tropospheric Emission Spectrometer (TES) to evaluate model tropospheric ozone and its effect on OLR simulated by a suite of chemistry-climate models that participated in the Atmospheric Chemistry and Climate Model Intercomparison Project (ACCMIP). The ensemble mean of ACCMIP models show a persistent but modest tropospheric ozone low bias (5-20 ppb) in the South-
\end{abstract}

ern Hemisphere ( $\mathrm{SH})$ and modest high bias (5-10 ppb) in the Northern Hemisphere (NH) relative to TES ozone for 2005-2010. These ozone biases have a significant impact on the OLR. Using TES instantaneous radiative kernels (IRK), we show that the ACCMIP ensemble mean tropospheric ozone low bias leads up to $120 \mathrm{~mW} \mathrm{~m}^{-2}$ OLR high bias locally but zonally compensating errors reduce the global OLR high bias to $39 \pm 41 \mathrm{~m} \mathrm{Wm}^{-2}$ relative to TES data. We show that there is a correlation $\left(R^{2}=0.59\right)$ between the magnitude 
of the ACCMIP OLR bias and the deviation of the ACCMIP preindustrial to present day (1750-2010) ozone radiative forcing (RF) from the ensemble ozone RF mean. However, this correlation is driven primarily by models whose absolute OLR bias from tropospheric ozone exceeds $100 \mathrm{~m} \mathrm{Wm}^{-2}$. Removing these models leads to a mean ozone radiative forcing of $394 \pm 42 \mathrm{~m} \mathrm{Wm}^{-2}$. The mean is about the same and the standard deviation is about $30 \%$ lower than an ensemble ozone RF of $384 \pm 60 \mathrm{~m} \mathrm{Wm}^{-2}$ derived from 14 of the 16 ACCMIP models reported in a companion ACCMIP study. These results point towards a profitable direction of combining satellite observations and chemistry-climate model simulations to reduce uncertainty in ozone radiative forcing.

\section{Introduction}

Tropospheric ozone plays a central role in both atmospheric chemistry and climate. Due to significant increases in anthropogenic emissions of its precursors since preindustrial times, tropospheric ozone has the third highest impact as an anthropogenic greenhouse gas in terms of radiative forcing, 350 [250-650] $\mathrm{m} \mathrm{Wm}^{-2}$ (Forster et al., 2007), but is distinguished from other greenhouse gases by having significant spatial and temporal heterogeneity due to its relatively short lifetime. Ozone is an essential part of the oxidative capacity of the troposphere, both as an oxidant in its own right, but especially as a precursor of the hydroxyl radical $(\mathrm{OH})$ (Wang and Jacob, 1998; Voulgarakis et al., 2013). Reaction with $\mathrm{OH}$ controls the chemical lifetime of many species in the atmosphere, including methane, providing a link between ozone concentrations and the global warming potential of methane (Shindell et al., 2005, 2009). In addition, changes in climate can affect the chemistry of ozone, including increasing the rate of $\mathrm{OH}$ production due to higher water vapor concentrations with warming temperatures, that will have impacts for methane and other gases, e.g., (Stevenson et al., 2006). Uncertainties in these processes impact knowledge of preindustrial ozone concentrations, the evolution of ozone, and present-day distributions. These factors contribute to the broad range of radiative forcing estimates in the IPCC.

Ozone can also indirectly affect the climate through the carbon and hydrological cycles. As it is a phytotoxin, increases in ozone can reduce global primary productivity and therefore the $\mathrm{CO}_{2}$ uptake by biota (plants, forests), potentially leading to an indirect forcing of a similar magnitude to the direct ozone forcing (Sitch et al., 2007; Collins et al., 2010). These interactions have yet to be explored across a suite of models.

Studies since the Intergovernmental Panel on Climate Change (IPCC) Fourth Assessment Report (AR4) have found that changes in short-lived species, including tropospheric ozone, are expected to have a significant impact on global temperatures, especially over the Northern Hemi- sphere (Levy et al., 2008; Shindell et al., 2008). In particular, by 2050, Short-Lived Climate Forcing (SLCF) agents could be responsible for up to $20 \%$ of simulated global mean annually averaged warming and up to 40 percent of the total projected summertime warming in the central United States from 2050-2100 (Levy et al., 2008). However, the contribution of short-lived species to simulated changes in globalmean surface temperature can have a strong dependence on both the SLCF magnitude and spatial distribution (Shindell and Faluvegi, 2009). These factors have been the impetus for policy formulation that mitigates both air quality and global warming, (West et al., 2006, 2007; van Vuuren et al., 2006; Wallack and Ramanathan, 2009; Ramanathan and Xu, 2010; Shindell et al., 2013) with the concomitant need for accurate measurements and model results.

The Atmospheric Chemistry and Climate Model Intercomparison Project was initiated to complement the Climate Model Intercomparison Project, Phase 5 (CMIP5) (Taylor et al., 2011) by focusing on the coupling of chemically active atmospheric constituents with climate both historically and in the future (Lamarque et al., 2013). A suite of stateof-the-art chemistry-climate models were driven by common emissions and comparable boundary conditions over different time periods from preindustrial to present-day. In addition, simulations of future climate were calculated using emissions derived from Representative Concentration Pathway (RCP) scenarios (van Vuuren et al., 2011). This approach can help quantify the role of SLCF in past and future climate response across a range of models, which was difficult to do previously (Shindell and Lamarque, 2009). Consequently, ACCMIP will be a valuable resource for the IPCC AR5.

Furthermore, a constellation of satellites that can observe a number of trace gas constituents are now available with global coverage and data records of sufficient length to be useful for the evaluation of ACCMIP simulations. Expanding from the analysis of Aghedo et al. (2011b), we evaluate how ACCMIP tropospheric ozone bias effects OLR bias using global, simultaneous observations of tropospheric ozone and sensitivity of OLR to tropospheric ozone from the Tropospheric Emission Spectrometer, which was launched aboard the NASA Aura spacecraft in 2004 (Beer, 2006), using data collected from 2005-2010. TES does not measure the full OLR but does measure spectral radiances in the 9.6 micron ozone band. However, tropospheric ozone has by far the strongest infrared absorption in the 9.6 micron band (Clough and Iacono, 1995). Consequently, the impact of tropospheric ozone on OLR bias can be computed from the 9.6 micron ozone band alone. We apply TES Instantaneous Radiative Kernels (IRK) to the ACCMIP tropospheric ozone bias in order to relate changes in the vertical structure of tropospheric ozone to changes in OLR $(\delta \mathrm{OLR})$ at the top-of-theatmosphere (TOA). The TES IRK quantifies the sensitivity of OLR to changes in the vertical distribution of tropospheric ozone for each satellite observation, accounting for 
the effects of temperature, water vapor and effective cloud properties that are simultaneously estimated (Worden et al., 2011). These corresponding state parameters largely determine atmospheric opacity and therefore control the magnitude of the IRK. Consequently, we quantify the change in OLR due to ACCMIP tropospheric ozone bias referenced against the observed atmospheric state as opposed to a model simulated atmospheric state.

We then explore the implications of ACCMIP OLR biases from tropospheric ozone on ozone radiative forcing (RF), which is defined as the net change in irradiance at the tropopause after stratospheric temperature adjustment due to changes in ozone concentrations from preindustrial to present day (Forster et al., 2007). Ozone RF is dependent on a number of factors, including preindustrial emissions, background concentrations (through lightning-derived NOx and stratospheric input), present-day concentrations, atmospheric radiative transfer, chemical mechanisms, and the physical climate (e.g. clouds, temperature, humidity). Uncertainties in these processes potentially could lead to biases in present day OLR. Hence, we investigate whether ACCMIP ozone RF is correlated with ACCMIP $\delta$ OLR.

\section{Tropospheric emission spectrometer}

Launched in July 2004, the NASA EOS Aura platform is in a polar, Sun-synchronous orbit with an equator crossing time of 13:40 and 02:29 local mean solar time for ascending and descending orbit paths, respectively. The Tropospheric Emission Spectrometer (TES) is a Fourier Transform Spectrometer (FTS) that measures spectrally-resolved outgoing longwave radiation of the Earth's surface and atmosphere at frequencies between $650-2250 \mathrm{~cm}^{-1}$ with unapodized spectral resolution of $0.06 \mathrm{~cm}^{-1}$ (Beer, 2006). This spectral resolution is sufficient to resolve pressure-broadened IR absorption lines in the troposphere and allows TES to estimate simultaneous vertical profiles of ozone, water vapor, carbon monoxide, methane, deuterated water vapor as well as atmospheric temperature. Previous studies used these profiles under clearsky scenes to estimate the greenhouse gas effect from upper tropospheric ozone to be $0.48 \pm 0.14 \mathrm{Wm}^{-2}$ (Worden et al., 2008). Effective cloud pressure and optical depth, surface temperature and land emissivity are also derived from TES spectral radiances, which allows TES to perform ozone retrievals in all-sky conditions (Eldering et al., 2008). Algorithms for radiometric calibration (Worden et al., 2007), retrieval of atmospheric parameters (Bowman et al., 2006), and error characterization (Worden et al., 2004) along with cloud property retrievals (Kulawik et al., 2006) have been described previously. The TES forward model used for computing spectral radiances and Jacobians (Clough et al., 2006) is based on LBLRTM (line-by-line radiative transfer model), which has been used as the basis for a number of radiative transfer models in climate models (Forster et al., 2011). TES radiances have been compared to other satellite and aircraft data (Shephard et al., 2008). There is no detectable trend in residual spectral radiances (observed minus calculated) from 2005-2009 to within 0.6 K (Connor et al., 2011). Previous validation studies of the TES ozone V002 product indicate ozone profiles are biased high in the troposphere $(\approx 15 \%)$ relative to ozonesondes (Nassar et al., 2008) and aircraft data (Richards et al., 2008) while total ozone columns are biased high by about 10 DU relative to OMI measurements (Osterman et al., 2008). The optimal estimation technique used operationally on TES data provides formal uncertainties (Bowman et al., 2002, 2006). These uncertainty estimates were tested by comparisons with northern latitude ozonesondes reported in Boxe et al. (2010), which showed that formal measurement and species interference errors were consistent with empirical calculations.

We use TES V004 ozone profile product for this study, which has been updated relative to the V002 product. Ozonesonde profile comparisons with the Intercontinental Chemical Transport Experiment Ozonesonde Network Study (IONS), the World Ozone and Ultraviolet Data Center (WOUDC), the Global Monitoring Division of the Earth System Research Laboratory (GMD-ESRL), and the Southern Hemisphere Additional Ozonesonde archives (SHADOZ) have been performed. Approximately 5000 matches with one or more of these data sources are found using the coincidence criteria of $\pm 3 \mathrm{~h}$ and a $300 \mathrm{~km}$ radius, spanning a latitude range and time-span from $72.5^{\circ} \mathrm{S}$ to $80.3^{\circ} \mathrm{N}$ from 2004 to 2008 . Analysis of the comparisons are documented in the TES Validation Report V4 http://eosweb.larc.nasa.gov/PRODOCS/tes/ validation/TES_Validation_Report_v40.pdf. In the Northern Hemisphere, the TES tropospheric ozone is biased high by about $10-15 \%$ throughout the free troposphere. In the tropics, the bias in the free troposphere is vertically dependent with about a $10 \%$ high bias at about $800 \mathrm{hPa}$ and decreasing to near zero at $200 \mathrm{hPa}$. The southern midlatitudes show similar features but are slightly low biased $(<5 \%)$ at $200 \mathrm{hPa}$. Comparisons of TES tropospheric ozone with ozonesondes by Young et al. (2013) show a similar sign and magnitude of bias.

\section{Instantaneous radiative kernels}

Following Worden et al. (2011), the logarithmic instantaneous radiative kernel (LIRK) is defined as the sensitivity of OLR at TOA to changes in the vertical distribution of tropospheric ozone:

$\frac{\partial F_{\mathrm{TOA}}}{\partial \ln q\left(z_{l}\right)}=\iint_{\nu} \int_{0}^{2 \pi} \int_{0}^{\frac{\pi}{2}} \frac{\partial L_{\mathrm{TOA}}(\nu, \theta, \phi)}{\partial \ln q\left(z_{l}\right)} \cos \theta \sin \theta d \theta d \phi d \nu$

where $v$ is frequency, $F_{\mathrm{TOA}}$ is the ozone band radiative flux from integrating over $v \in[985,1080] \mathrm{cm}^{-1}, q$ is an ozone 

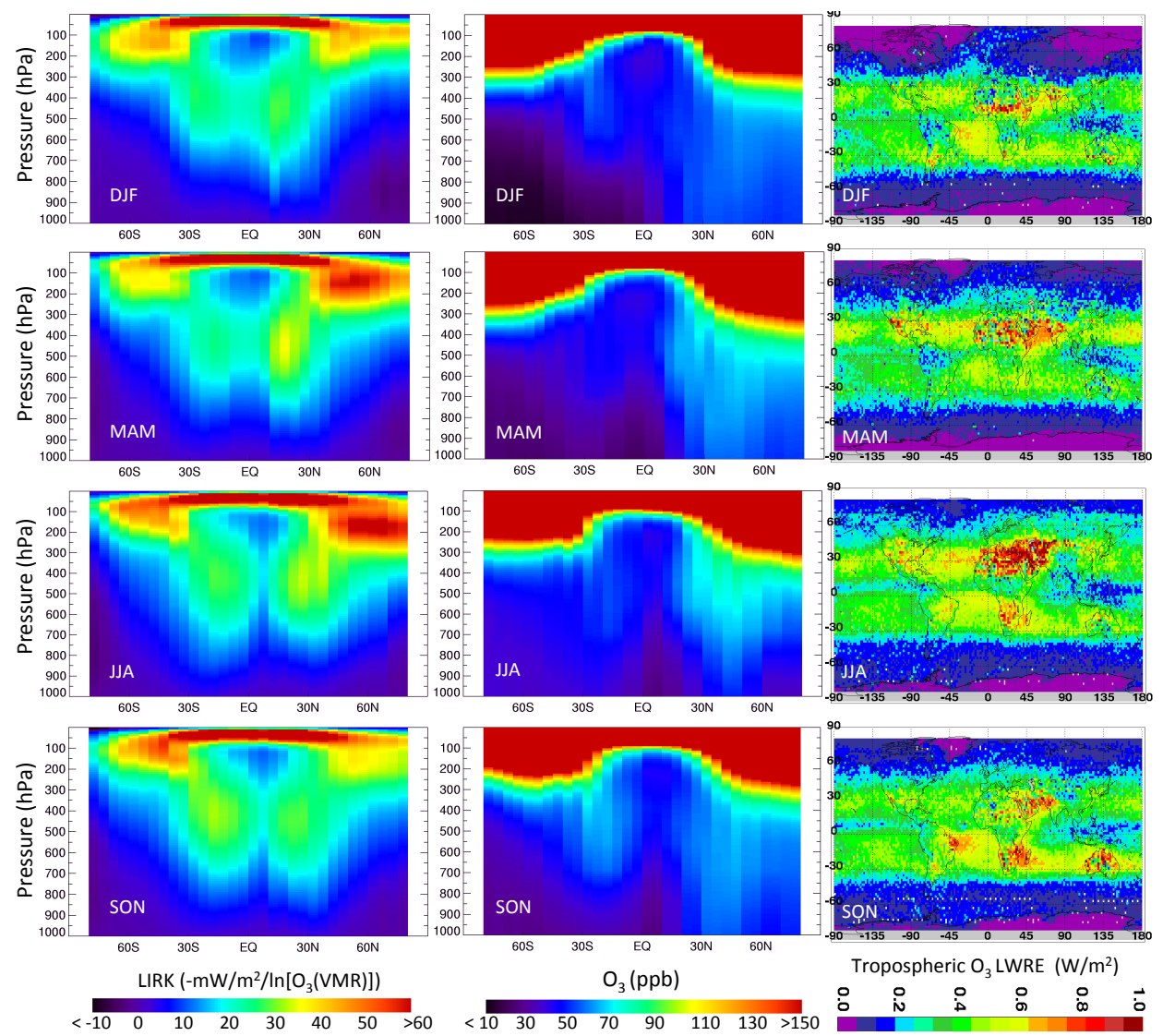

Fig. 1. Logarithmic instantaneous radiative kernels (LIRK) in $\mathrm{mWm}{ }^{-2} / \ln \left(\mathrm{vmr}_{\mathrm{O}_{3}}\right.$ ), TES zonal ozone in parts-per-billion (ppb), and longwave radiative effect (LWRE) in $\mathrm{Wm}^{-2}$ are shown along across each column respectively. Each row represents data averaged for 2005-2009 for December-January-February (DJF), March-April-May (MAM), June-July-August (JJA), and September-October-November (SON).

profile in volume mixing ratio as a function of altitude $z$ at level $l, L_{\mathrm{TOA}}$ is the spectral radiance at frequency $v$, zenith angle $\phi$ and azimuth angle $\theta$. The partial derivatives of spectral radiance $L_{\mathrm{TOA}}$ are provided by the TES operational radiative transfer algorithm, (Clough et al., 2006), and are used within the retrieval algorithm to estimate the vertical distributions of trace gases, temperature, water vapor, and clouds (Worden et al., 2004; Bowman et al., 2006). Changes in other atmospheric parameters are incorporated into the LIRK, e.g., retrieved cloud top height will change the altitudes for which $F_{\mathrm{TOA}}$ is sensitive to ozone variations. From Eq. (1), increases in tropospheric ozone lead to a reduction in OLR consistent with the ozone greenhouse gas effect.

Equation (1) is treated as an operator in a first order Taylor series expansion to calculate the ACCMIP OLR bias from tropospheric ozone as

$\delta \operatorname{OLR}_{l}^{j, m}=H_{j}\left(z_{l}\right)\left[\ln q_{j}^{m}\left(z_{l}\right)-\ln q_{j}^{o b s}\left(z_{l}\right)\right]$

where $q_{j}^{m}\left(z_{l}\right)$ and $q_{j}^{o b s}\left(z_{l}\right)$ are the model and TES ozone, respectively, at the $j^{\text {th }}$ location and the $l^{\text {th }}$ altitude level while
$H_{j}\left(z_{l}\right)=\frac{\partial F_{\mathrm{TOA}}^{j}}{\partial \ln q_{j}\left(z_{l}\right)}$

is the LIRK at location $j$ and evaluated at altitude $z_{l}$ discretized at levels $l$. Consistent with the ozone greenhouse gas effect, the LIRK is negative for increases in tropospheric ozone so that for a positive tropospheric ozone bias between a model and TES at an altitude $z_{l}, \delta \mathrm{OLR}_{l}^{j, m}<0$. In the subsequent sections, the level $l$ will also refer to corresponding pressure levels.

The total longwave radiative effect (LWRE) is calculated by integrating Eq. (3) in altitude to the tropopause. The LWRE can be thought of as the reduction in OLR to a $100 \%$ change in the tropospheric ozone profile (Worden et al., 2011). Note that the LWRE is a logarithmic change referenced to TES ozone and consequently it can not be used to calculate the change to a complete absence of ozone.

TES ozone, LIRK, and LWRE averaged for 2005-2009 are shown in Fig. 1. The LWRE was integrated to the thermal tropopause height derived from the Goddard Modeling and Assimilation Office (GMAO) GEOS-5 (Molod et al., 2012). There is a strong sensitivity in the LIRK of up to $35 \mathrm{~m} \mathrm{Wm}^{-2}$ 
in the mid-troposphere extending as low as $600 \mathrm{hPa}$ and arcing poleward to $200 \mathrm{hPa}$ at $60^{\circ} \mathrm{N}$ and $60^{\circ} \mathrm{S}$. The LIRK increases in the upper troposphere and lower stratosphere with sensitivities well above $60 \mathrm{~m} \mathrm{Wm}^{-2}$ per unity change in $\ln q$. The LIRK spatial pattern is remarkably similar to climatological relative humidity $(\mathrm{RH})$ distributions, which are at a minimum in subsidence regions especially in the Southern Hemispheric sub-tropics. Interestingly, low RH in the SH sub-tropics have been linked to equilibrium climate sensitivity (Fasullo and Trenberth, 2012). This similarity suggests that the LIRK sensitivity is driven primarily by atmospheric opacity which in turn is controlled by a combination of temperature, water vapor, and clouds. There is a seasonal migration of the LIRK maximum across the equator, which follows the change in the inter-tropical convergence zone (ITCZ) and is driven primarily by the seasonal shift in cloud distributions.

The seasonal pattern of ozone in the SH is strongly influenced by the presence of biomass burning and lightning leading to a maximum of 60-70 ppb in September-OctoberNovember (SON). The impact of biomass burning and lightning in South America, sub-equatorial Africa, and Indonesia are clearly seen. Near source regions, the LWRE exceeds $1 \mathrm{Wm}^{-2}$ during SON. During December-January-February (DJF), ozone from biomass burning in Africa north of the (ITCZ) has similarly high LWRE. In most months, there is a persistently high LWRE $\left(>1 \mathrm{Wm}^{-2}\right)$ over the Middle East. This is driven in part by relatively clear skies and a strong thermal contrast that amplifies the ozone greenhouse gas effect. However, in the summer months, there is an ozone enhancement in the middle troposphere $(400-500 \mathrm{hPa})$ induced by trapping from Saharan and Arabian anticyclones, which also corresponds to the highest magnitude LIRK values in the middle troposphere (Li et al., 2001; Liu et al., 2009).

\section{Methodology}

\subsection{Radiative forcing}

Radiative forcing (RF) is a measure of the energy imbalance of the Earth-atmosphere system and is used as a means of quantifying the potential of external agents to perturb that system. In the context of historic climate change, the perturbation is referenced from preindustrial (1750s) to the presentday (2000s). In order for the ozone forcing to be taken as a reasonable proxy for the expected temperature response, $\mathrm{RF}$ is specifically defined as the change in net irradiance at the tropopause after stratospheric temperatures have relaxed to radiative-dynamical equilibrium but with the surface and atmospheric state held fixed (Forster et al., 1997, 2007). The forcing-response relationship, however, can be more complicated depending on the forcing agent and its distribution (Fels et al., 1980; Hansen et al., 1997, 2007; Shindell and Faluvegi, 2009). Methods of calculating tropo- spheric ozone RF from models using "off-line" techniques, i.e., radiative transfer calculations performed independently of a climate model's internal radiation calculation, follow two steps. The first step is to calculate the change in ozone concentrations by forcing a global chemistry-climate model with pre-industrial (usually taken in the 1750s) and presentday concentrations in separate "time-slices", which is an interval of time, e.g., 1750-1760. The second step is to calculate the change in longwave and shortwave radiation due to the change in present-day ozone relative to the pre-industrial era using an "off-line" radiative transfer model (RTM) where stratospheric temperatures are allowed to equilibrate resulting in an adjusted irradiance (Edwards and Slingo, 1996; Stevenson et al., 2006; Knutti and Hegerl, 2008; Stevenson et al., 2013). Radiative forcing is generally referenced at the tropopause, the definition of which can have a significant impact on the final calculation, e.g. flat tropopause set at 100,150 or $200 \mathrm{hPa}$, zonally invariant and linear with latitude tropopause (Naik et al., 2005; Hansen et al., 2007), chemical tropopause using the $150 \mathrm{ppbv}$ ozone level (Stevenson et al., 2006), and the WMO thermal tropopause (Aghedo et al., 2011b). Radiative forcing is simply the difference between the irradiance at two different time periods, which can be expressed as:

$\mathrm{RF}^{m}=R\left(\mathbf{q}_{p}^{m}\right)-R\left(\mathbf{q}_{o}^{m}\right)$

where $R$ is the globally, area-weighted average net irradiance (shortwave (SW) plus longwave (LW)) in $\mathrm{m} \mathrm{Wm}^{-2}$ including stratospheric readjustment, $\mathbf{q}_{p}^{m}$ is the vertical distribution (discretized as a vector) of present-day ozone simulated by model $m$, and $\mathbf{q}_{o}^{m}$ is preindustrial ozone for the same model. Implicit in Eq. (4) is temporal averaging over some time-slice.

\subsection{Application to TES data}

TES observations directly measure the 9.6 micron ozone band radiances (the primary band where ozone absorbs thermal infrared radiation) and have the spectral resolution to disentangle the geophysical quantities, e.g., temperature and clouds, driving ozone band radiative flux variability. These data have the potential to assess model results with respect to the longwave component of ozone radiative forcing. However, differences between satellite and climate model calculations need to be considered. TES only measures thermal radiance at the top-of-the-atmosphere (TOA). Consequently, these measurements do not provide information on the shortwave irradiance. Chemistry-climate models calculate the full global and diurnal cycle of ozone whereas TES has a global repeat cycle of 16 days and can only measure twice a day through its ascending and descending nodes. However, Aghedo et al. (2011a) showed that TES sampling is sufficient to capture zonal scale variations in ozone when compared to chemistry-climate model simulations. 
The mean ACCMIP bias in OLR from tropospheric ozone is calculated from Eq. (2) as

$\delta \mathrm{OLR}_{m}^{j}=\frac{1}{N_{j}} \sum_{i \in D_{j}} \sum_{l \in L} w_{i} H_{i, l}\left(\ln \left[\mathbf{q}_{p}^{m}\right]_{i, l}-\ln \left[\mathbf{q}_{p}^{\mathrm{obs}}\right]_{i, l}\right)$

where $w_{i}$ are area-weights (to account for the relative areas of different latitude bands), $D_{j}$ is a set of observed locations, $N_{j}$ is the number of locations in set $D_{j}$, and $L$ is the set of altitude levels whose maximum value is at the tropopause, which we choose to be the chemical tropopause $q=150 \mathrm{ppb}$. The domain $D_{j}$ can be comprised of either grid cells or zonal bands. In either case, we will define the OLR bias as $\delta \mathrm{OLR}_{m}^{j}$ where $j$ refers to latitudinal bands or individual grid boxes depending on the context described in the subsequent sections. The global mean OLR bias from tropospheric ozone is calculated by averaging over all $D_{j}$ and will be denoted as $\delta \mathrm{OLR}_{m}$. The ACCMIP ensemble mean OLR bias from tropospheric ozone will be denoted as $\overline{\delta \mathrm{OLR}}_{j}$ for locations $D_{j}$ and the ensemble global mean is simply $\overline{\delta \text { OLR }}$. Implicit in Eq. (5) is temporal averaging from 2005-2010.

\section{Results}

\subsection{ACCMIP simulations}

We use TES observations to evaluate the OLR bias from tropospheric ozone in the chemistry-climate models that participated in ACCMIP. A complete description of the chemistry-climate and chemical transport models along with their short hand designation (CESM-CAM-superfast, CICERO-OsloCTM2, CMAM, GEOSCCM, GFDL-AM3, GISS-E2-R, GISS-E2-TOMAS, HadGEM2, LMDzORINCA, MIROC-CHEM, MOCAGE, NCAR-CAM3.5, STOC-HadAM3, UM-CAM) can be found in Lamarque et al. (2013). Each were driven by a common set of emissions (Lamarque et al., 2010). The experimental design was based on decadal "time-slice" experiments driven by decadal mean sea surface temperatures (SST). The historic periods included 1850, 1980, and 2000 along with 2030 and 2100 time slices that follow the representative concentration pathways (RCP) (van Vuuren et al., 2011). As described by Lamarque et al. (2013) the level of complexity in the chemistry schemes varied significantly between the models. The physical climate was based on prescribed SSTs for most models with the notable exception of the GISS model, which is integrated with a fully coupled ocean-atmosphere model (Shindell et al., 2013). Following Young et al. (2013), model simulations for the 2000 decade were averaged and then interpolated to the domain of the gridded TES product archived along with the ACCMIP simulations at the British Atmospheric Data Archive (BADC), which is composed of 64 pressure levels at $2 \times 2.5^{\circ}$ spatial resolution. These decadal mean model simulations are then compared against TES tropospheric ozone for 2005-2010.

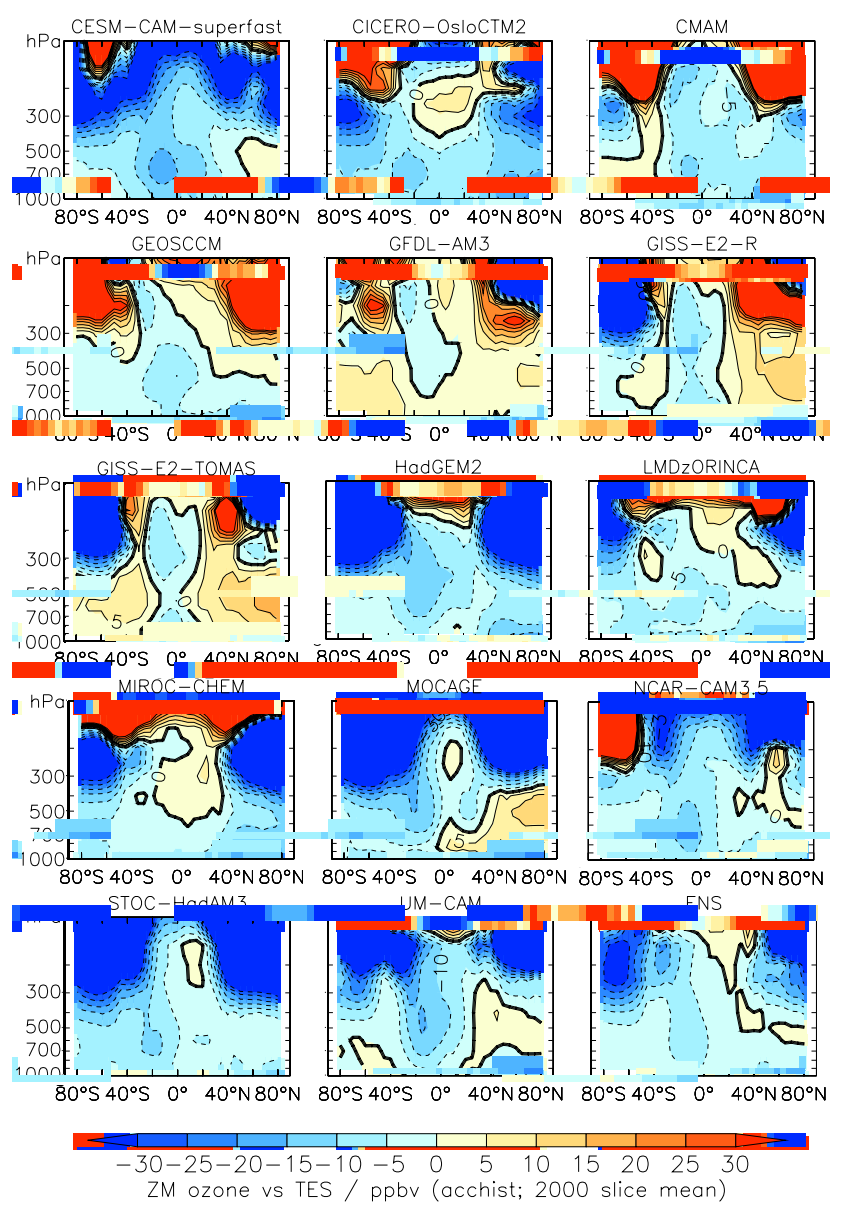

Fig. 2. Zonal bias between ACCMIP models and TES ozone averaged over 2005-2010. Ensemble average of ACCMIP compared to TES ozone is shown under ENS in the bottom right.

\subsection{Application to ACCMIP models}

We first compare the zonal-vertical difference between the ACCMIP and TES tropospheric ozone from 2005-2010 as shown in Fig. 2 including the ensemble (ENS) in the bottom right. There is a rich diversity in the zonal ozone distribution. In the middle to lower troposphere the agreement is generally within 10-15 ppb. In the Northern Midlatitudes (NMLT), the GISS-E2-R, GISS-E2-TOMAS, and MOCAGE were larger than TES ozone estimates by more than $10 \mathrm{ppb}$. On the other hand, CICERO-OsloCTM2, HadGEM2, MIROCCHEM, and CMAM tend to underestimate NMLT ozone relative to TES ozone. In the tropical troposphere, most models tend to underestimate ozone. The upper troposphere and lower stratosphere show stronger differences. The CMAM and MIROC-CHEM models have significantly higher ozone in both the NMLT and the Southern Midlatitudes (SMLT). Conversely, MOCAGE, HadGEM2, STOC-HadAM3, and UM-CAM estimate lower ozone than TES ozone in both the NMLT and SMLT. However, the TES observation operator is 


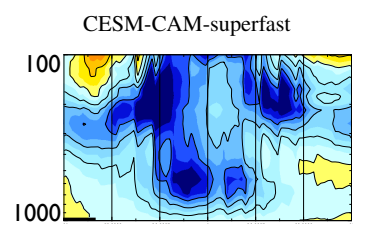

GEOSCCM

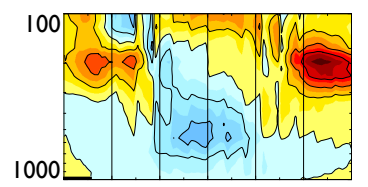

GISS-E2-R-TOMAS

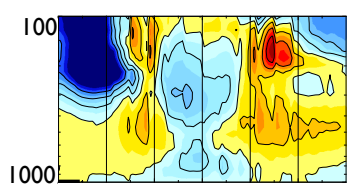

MIROC-CHEM

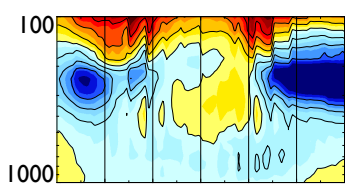

STOC-HadAM3

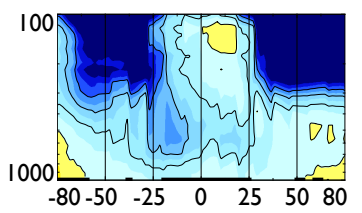

CICERO-OsloCTM2

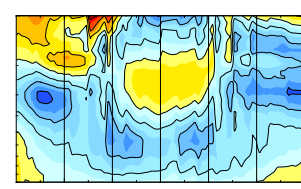

GFDL-AM3

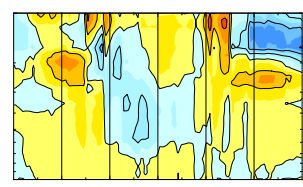

HadGEM2

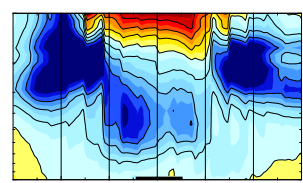

MOCAGE

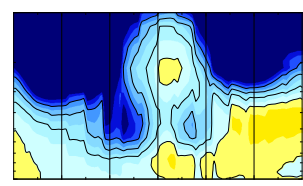

UM-CAM

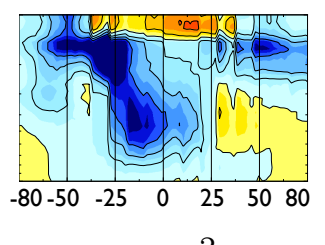

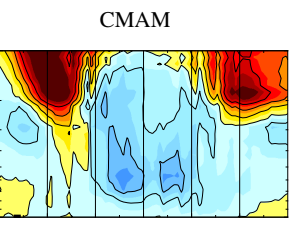

GISS-E2-R

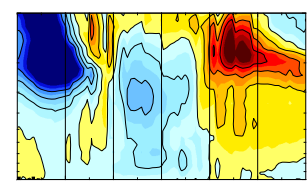

LMDzORINCA

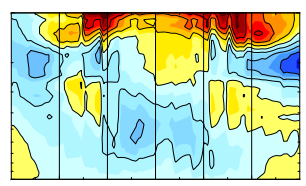

NCAR-CAM 3.5

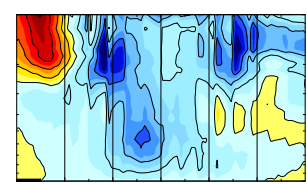

ENS

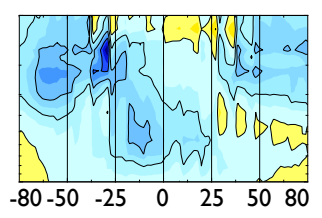

$\mathrm{mWm}^{-2}$

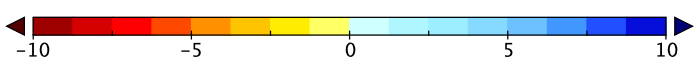

Fig. 3. Zonal distribution of ACCMIP OLR bias from tropospheric ozone, $\delta \mathrm{OLR}_{l}^{j, m}$, from 2005-2010. The vertical scale is defined from $1000-100 \mathrm{hPa}$ discretized to TES pressure levels. Color scale is inverted to show that positive $\delta \mathrm{OLR}_{l}^{j, m}$ is a model low ozone bias relative to TES. Ensemble mean bias $\overline{\delta \mathrm{OLR}}_{l}^{j}$ is denoted by ENS.

not applied to these models as Aghedo et al. (2011b), nor is there any bias correction applied to the TES data. Based on ozonesonde comparisons discussed in Sect. 2, TES ozone is systematically high in the Northern Hemisphere, which suggests that the high ozone biases in GISS-E2-R and MOCAGE are exacerbated but the slight low ozone bias in the ensemble distribution is likely insignificant. TES upper tropospheric ozone in the tropics is consistent with ozonesonde measurements, which indicates that the ensemble model low bias is robust.

The ACCMIP OLR bias from tropospheric ozone, $\delta \mathrm{OLR}_{l}^{j, m}$, which is calculated from Eq. (2), is shown in Fig. 3 discretized at TES pressure levels. The zonal cross-section in this figure can be related to the ACCMIP ozone bias in Fig. 2 through Eq. (2). For example, in Fig. 2 a 10 ppb low bias of GISS-E2-R relative to TES ozone at $300 \mathrm{hPa}$ and $15^{\circ} \mathrm{S}$ leads to a $\delta \mathrm{OLR}_{l}^{j, m}$ of about $5 \mathrm{~m} \mathrm{Wm}^{-2}$ at the same location as shown in Fig. 3. As quantified by the LIRK in Fig. 1, the thermal contrast between the temperature at which the ozone absorbs in the troposphere and the surface temperature along with the low humidity, which decreases atmospheric opacity, contributes to the importance of the tropics and subtropics relative to the high latitudes. Consequently, underestimates of tropical and subtropical ozone are amplified in terms of $\delta \mathrm{OLR}_{l}^{j, m}$ relative to the extratropics. Almost half of the ACCMIP models have $\delta \mathrm{OLR}_{l}^{j, m}$ that exceeds $10 \mathrm{~m} \mathrm{Wm}^{-2}$ at individual pressure levels $l$. Radiatively significant differences are not confined to the upper troposphere. 


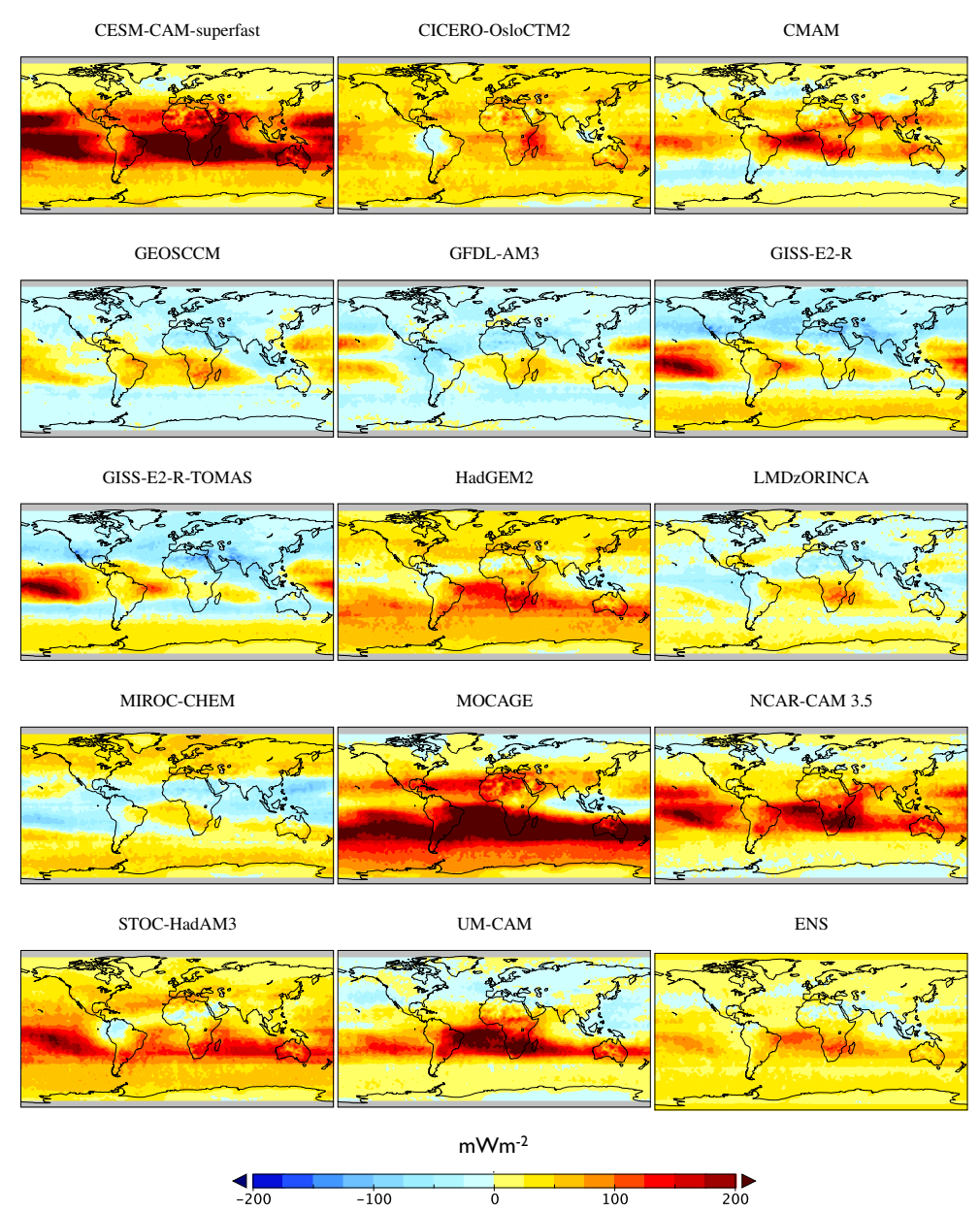

Fig. 4. Spatial distribution of ACCMIP OLR bias from tropospheric ozone, $\delta \mathrm{OLR}_{m}^{j}$, from $2005-2010$, limited to $80^{\circ} \mathrm{S}-80^{\circ} \mathrm{N}$, and based on a chemical tropopause $q=150 \mathrm{ppb}$ as diagnosed from TES. ACCMIP ensemble, $\overline{\delta \mathrm{OLR}}_{j}$, is denoted by ENS.

In several models, tropical differences in ozone at pressures greater than $600 \mathrm{hPa}$ lead to $\delta \mathrm{OLR}_{l}^{j, m}>10 \mathrm{~m} \mathrm{Wm}^{-2}$.

The ACCMIP OLR bias from tropospheric ozone is the ACCMIP tropospheric ozone bias weighted by the LIRK. Comparing the LIRK distributions in Fig. 1 to the $\delta \mathrm{OLR}_{l}^{j, m}$ in Fig. 3 suggest that in the tropics and $\mathrm{SH}, \delta \mathrm{OLR}_{l}^{j, m}$ from models such CESM-superfast, HadGEM-2, MOCAGE, UMCAM, NCAR-CAM 3.5, STOC-HadAM3 has a strong influence from the LIRK, particularly the positive $\delta \mathrm{OLR}_{l}^{j, m}$ at $500 \mathrm{hPa}$ around $10-15^{\circ} \mathrm{S}$ and extending poleward up to $100 \mathrm{hPa}$ around $50^{\circ} \mathrm{S}$. This LIRK spatial pattern is persistent across a number of models in $\mathrm{SH}$ as can be seen in the ACCMIP ensemble mean $\overline{\delta O L R}_{l}^{j}$ in Fig. 3. In the NH high latitudes, such as with GISS-E2-R at $60^{\circ} \mathrm{N}$ and $600 \mathrm{hPa}$, there is a significant bias in ozone but the attenuated OLR sensitivity makes $\delta \mathrm{OLR}_{l}^{j, m}$ relatively small.

A complimentary perspective is shown in Fig. 4, which shows $\delta \mathrm{OLR}_{m}^{j}$ calculated from Eq. (5) where $\delta \mathrm{OLR}_{l}^{j, m}$ at each location $j$ is vertically integrated up to the chemical tropopause of $q=150 \mathrm{ppb}$ diagnosed from TES ozone. Most ACCMIP models have a positive $\delta \mathrm{OLR}_{m}^{j}$ in the SH tropics because they underestimate tropospheric ozone relative to TES tropospheric ozone. The overestimate in the Eastern Tropical Atlantic is a persistent feature in all of the ACCMIP models and is reflected in the ensemble mean. Tropospheric ozone distributions in the tropical Atlantic are driven by a number of processes but are dominated by lightning (Jacob et al., 1996; Jenkins and Ryu, 2004; Sauvage et al., 2007; Bowman et al., 2009). A second persistent feature is the overestimate centered over Southern Africa. Southern equatorial Africa is an important source of biomass burning (Edwards et al., 2006; Aghedo et al., 2007). Satellite-based "topdown" estimates indicate the emissions from biomass burning are significantly underestimated (Arellano et al., 2006; Jones et al., 2009). Local sources of pollution and biomass burning have been associated with upward trends in ozone, particularly in the lower troposphere (Clain et al., 2009). However, the Southern African region has a complex circulation pattern that includes both anticyclonic transport and 


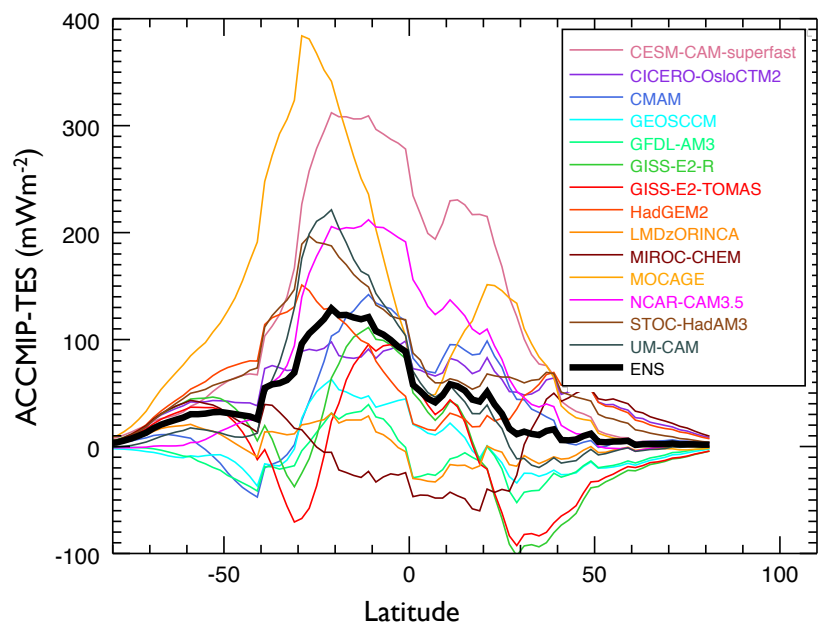

Fig. 5. Zonal $\delta \mathrm{OLR}_{m}^{j}$ between ACCMIP and TES from 2005-2010, limited to $80^{\circ} \mathrm{S}-80^{\circ} \mathrm{N}$, and is based on a TES diagnosed chemical tropopause $(q=150 \mathrm{ppb})$. The "ENS" refers to the ACCMIP ensemble average, $\overline{\delta \mathrm{OLR}}_{j}$. Positive values indicate model ozone is biased low relative to TES ozone and consequently the model OLR is biased high relative to TES OLR.

recirculation as well as direct eastward and westward transport (Garstang et al., 1996; Sinha et al., 2004). Upwind sources of ozone precursors from biomass burning, pollution, and lightning can be advected across Southern Africa and out to the remote Pacific (Chatfield and Delany, 1990; Chatfield et al., 2002). Some of the radiatively strongest differences $\left(>200 \mathrm{~mW} / \mathrm{m}^{2}\right)$ in $\delta \mathrm{OLR}_{m}^{j}$, e.g, GISS-E2-R and NCAR-CAM3.5, are throughout the tropical Pacific, which may contribute to the positive $\mathrm{SH} \overline{\delta \mathrm{OLR}}_{j}$. The ACCMIP ensemble shows a persistent pattern in the tropical Pacific with a local maximum near $75 \mathrm{~m} \mathrm{Wm}^{-2}$. Comparison of the tropical distribution in Fig. 4 with the zonal-vertical distribution in Fig. 3 of $\delta \mathrm{OLR}_{m}^{j}$, points to the combination of low ozone throughout the troposphere that is amplified by the strong mid-tropospheric radiative sensitivity of the southern branch of the LIRK in Fig. 1. Tropical ozone is sensitive to convective mass flux, height, and subsidence, particularly in the Eastern Pacific (Liu et al., 2010). These factors in conjunction with ozone precursor uncertainties could help explain these features, though they are more prevalent during El Niño periods such as in 2006 (Nassar et al., 2009; Chandra et al., 2009) which are not well simulated in ACCMIP due to decadally averaged SST boundary conditions.

The SH tropics and subtropics dominate radiative differences as shown by the vertically integrated zonal distribution in Fig. 5. The ensemble mean $\overline{\delta \mathrm{OLR}}_{j}$ is high by about $120 \mathrm{~m} \mathrm{Wm}^{-2}$ between $10-20^{\circ} \mathrm{S}$. The mean bias is strongly influenced by MOCAGE, CESM-CAM, and NCAR-CAM3.5, whose $\delta \mathrm{OLR}_{m}^{j}$ varies from 200$400 \mathrm{~m} \mathrm{Wm}^{-2}$ though the latter two are driven by similar physical climate models. In the NH extratropics, the en-

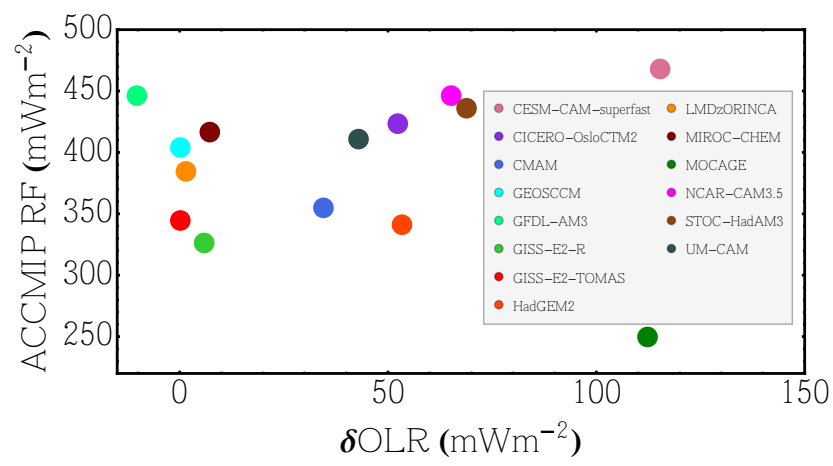

Fig. 6. ACCMIP ozone radiative forcing from preindustrial to present day as a function of $\delta \mathrm{OLR}_{m}$, which is the difference between ACCMIP model ozone and TES ozone weighted by the TES Instantaneous Radiative Kernel. The $\delta$ OLR is integrated through the TES diagnosed chemical tropopause $q=150 \mathrm{ppb}$ and averaged from 2005-2010.

semble mean ${\overline{\delta \mathrm{OLR}_{j}}}_{j} \approx 0 \mathrm{mWm}^{-2}$ with the extrema near $100 \mathrm{~m} \mathrm{Wm}^{-2}$ at $30^{\circ} \mathrm{N}$ decreasing poleward at a rate between linear and exponential. Systematic overestimates in the northern high latitudes in the TES ozone data will not strongly effect the ensemble mean bias because of the lower OLR sensitivity to tropospheric ozone. On the other hand, the $\mathrm{SH}$ low bias is robust because of the small upper tropospheric system errors in the TES retrieval.

\subsection{Implications for ACCMIP ozone radiative forcing}

We explore whether present-day OLR model bias from tropospheric ozone is correlated with model ozone RF and whether this relationship can be used to reduce our uncertainty in preindustrial to present day ozone RF. The cause of ACCMIP OLR bias from tropospheric ozone is a complex combination of uncertainties related to both the physical and chemical climate. Some of these differences are related to natural background conditions, e.g., lightning $\mathrm{NO}_{\mathrm{x}}$. Model biases for present-day background ozone may be expected to be correlated with respective biases from pre-industrial background ozone. Young et al. (2013) showed, for example, that ACCMIP models with high ozone burdens over the presentday had high burdens for the other periods of time including the preindustrial period. Uncertainties in present day emissions and their chemical transformation could result in significant biases in tropospheric ozone. Consequently, present day measurements have the potential to inform preindustrial to present day ozone radiative forcing.

In Table 1 , the domain $D_{j}$ of $\delta \mathrm{OLR}_{m}^{j}$ in Eq. (5) is defined for the tropics $\left(15^{\circ} \mathrm{S}-15^{\circ} \mathrm{N}\right)$, $\mathrm{NH}$ and $\mathrm{SH}$ extra-tropics. Tropical biases contributed the most to the global $\delta \mathrm{OLR}_{m}$ with some zonal $\delta \mathrm{OLR}_{m}^{j}>250 \mathrm{~m} \mathrm{Wm}^{-2}$. There are 5 of the 15 models with tropical $\delta \mathrm{OLR}_{m}^{i}>100 \mathrm{~m} \mathrm{Wm}^{-2}$. While most of the models underestimate ozone in the tropics-and hence have a positive $\delta \mathrm{OLR}_{m}^{j}$, there are 2 models that have 
Table 1. ACCMIP OLR bias from tropospheric ozone $\left(\delta \mathrm{OLR}_{m}^{j}\right)$ and ozone radiative forcing $\left(\mathrm{RF}^{m}\right)$ in $\mathrm{mWm}^{-2}$. The ozone $\mathrm{RF}^{m}$ is taken from (Stevenson et al., 2013) and is defined relative to 1750 and at a climatological thermal tropopause. The ACCMIP ensemble mean and $1-\sigma$ are shown in the last column of the first two rows. Tropics are defined from $15^{\circ} \mathrm{S}-15^{\circ} \mathrm{N}$.

\begin{tabular}{lrrrrr}
\hline Model & Tropics $\delta \mathrm{OLR}_{m}^{j}$ & $\mathrm{SH} \delta \mathrm{OLR}_{m}^{j}$ & $\mathrm{NH} \delta \mathrm{OLR}_{m}^{j}$ & Total $\mathrm{OLR}_{m}$ & $\mathrm{RF}^{m}$ \\
\hline ENS & 79 & 47 & 12 & 39 & 389 \\
ENS STDev & 75 & 49 & 32 & 41 & 60 \\
CESM-CAM-superfast & 256 & 103 & 59 & 115 & 468 \\
CICERO-OsloCTM2 & 81 & 49 & 42 & 52 & 423 \\
CMAM & 106 & 11 & 23 & 35 & 355 \\
GEOSCCM & 29 & 2 & -16 & 0 & 404 \\
GFDL-AM3 & 1 & -8 & -18 & -10 & 446 \\
GISS-E2-R & 67 & 24 & -41 & 6 & 326 \\
GISS-E2-R-TOMAS & 65 & 6 & -37 & 0 & 345 \\
HadGEM2 & 50 & 75 & 33 & 53 & 341 \\
LMDzORINCA & -6 & 13 & -6 & 1 & 384 \\
MIROC-CHEM & -37 & 20 & 16 & 7 & 416 \\
MOCAGE & 129 & 169 & 48 & 112 & 250 \\
NCAR-CAM3.5 & 168 & 54 & 26 & 65 & 446 \\
STOC-HadAM3 & 101 & 85 & 37 & 69 & 436 \\
UM-CAM & 96 & 61 & -1 & 43 & 411 \\
\hline
\end{tabular}

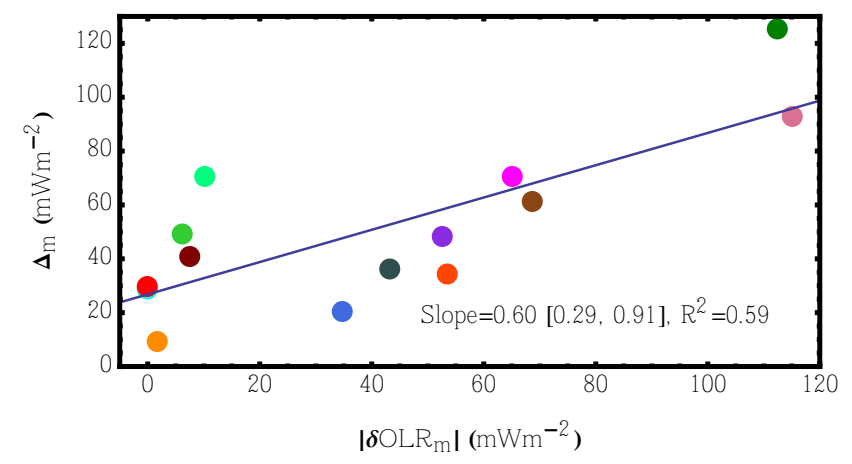

Fig. 7. The deviation of ACCMIP ozone radiative forcing from an ensemble mean versus $\left|\delta \mathrm{OLR}_{m}\right|$, which is the magnitude of the difference between model ozone and TES ozone weighted by the TES Instantaneous Radiative Kernel. The mean is calculate from an subset of models whose $\left|\delta \mathrm{OLR}_{m}\right|<10 \mathrm{~m} \mathrm{Wm}^{-2}$. The $\delta$ OLR is integrated through the TES diagnosed chemical tropopause $q=$ $150 \mathrm{ppb}$ and averaged from 2005-2010. The correspondence between the colors and models is the same as in Fig. 6. The brackets for the slope represent the uncertainty at the $95 \%$ confidence.

a negative $\delta \mathrm{OLR}_{m}^{j}$. Similarly, the $\mathrm{SH} \delta \mathrm{OLR}_{m}^{j}$ reaches as much as $170 \mathrm{~m} \mathrm{Wm}^{-2}$. The $\mathrm{NH}$ has a much wider response with about half of the models having a $\delta \mathrm{OLR}_{m}^{j}$ as high as $60 \mathrm{~m} \mathrm{Wm}^{-2}$. There are 5 models whose total $\delta \mathrm{OLR}_{m}$ are less than $10 \mathrm{~m} \mathrm{Wm}^{-2}$ whereas most are greater than $30 \mathrm{~m} \mathrm{Wm}^{-2}$. The ensemble mean and standard deviation for $\delta \mathrm{OLR}_{m}$ is $\overline{\delta \mathrm{OLR}}=39 \pm 41 \mathrm{~m} \mathrm{Wm}^{-2}$, which reflects this variability.

In order to explore the implications of these biases on ozone radiative forcing, the global $\delta \mathrm{OLR}_{m}$ is compared to ACCMIP ozone RF in Fig. 6. The ACCMIP ozone RF is based on the climatological thermal tropopause and the ozone RF has been extended from 1850 to 1750 by adding $40 \mathrm{~m} \mathrm{Wm}^{-2}$ (Skeie et al., 2011; Stevenson et al., 2013). There is a wide range of ozone RF estimates from $210-428 \mathrm{~m} \mathrm{Wm}^{-2}$ with a mean of $384 \pm 60 \mathrm{~m} \mathrm{Wm}^{-2}$. To investigate whether there is a relationship between model ozone RF and the magnitude of $\delta \mathrm{OLR}_{m}$ we first choose a subset of models whose $\left|\delta \mathrm{OLR}_{m}\right|<10 \mathrm{~m} \mathrm{Wm}^{-2}$ (GEOSCCM,GISS-E2R,GISS-E2R-TOMAS,LMDzORINCA,MIROC-CHEM). The ozone RF mean and standard deviation of this subset is $375 \pm 38.4 \mathrm{~m} \mathrm{Wm}^{-2}$. We then calculate the ozone RF absolute deviation of all the ACCMIP models with respect to the subset mean as

$\triangle_{m}=\left|\bar{R}_{\mathrm{S}}-R^{m}\right|$

where $\bar{R}_{\mathrm{S}}$ is the subset ACCMIP ensemble mean ozone RF. The ACCMIP deviation is shown as a function of $\left|\delta \mathrm{OLR}_{m}\right|$ in Fig. 7. The color scheme in Fig. 7 is the same as in Fig. 6. The slope of the linear fit shown in Fig. 7 is 0.60 with a $95 \%$ confidence interval of $[0.29,0.91]$ and $R^{2}=$ 0.59 . This correlation is largely driven by two models whose $\left|\delta \mathrm{OLR}_{m}\right|>100 \mathrm{~m} \mathrm{Wm}^{-2}$. If these models are not included then $R^{2}=0.18$ and the null hypothesis, i.e., there is no significant relationship between ACCMIP OLR bias and ozone $\mathrm{RF}$, can only be rejected at the $80 \%$ confidence level. It's interesting to note that these two models - CESM-CAM and MOCAGE - have the highest (538) and lowest (309), respectively, ozone radiative forcing. The ozone RF is driven in part by a change of only 4.8 Dobson Units (DU) in ozone for MOCAGE but a 10 DU ozone change for CESM-CAM from 
preindustrial to present-day (Stevenson et al., 2013; Young et al., 2013).

The difference in correlation between the ACCMIP ensemble subgroups provides a reasonable basis for ensemble selection. As a limitation for ensemble selection, TES observations can not be used to distinguish between models for which there is no correlation between model OLR bias from tropospheric ozone and model ozone RF. Therefore, models are selected for which $\left|\delta \mathrm{OLR}_{m}\right|<100 \mathrm{~m} \mathrm{Wm}^{-2}$ and therefore $\Delta_{m}<86 \mathrm{~m} \mathrm{Wm}^{-2}$. The ACCMIP radiative forcing under these conditions is $394 \pm 42 \mathrm{~m} \mathrm{Wm}^{-2}$. The mean is about the same and the standard deviation has been reduced by $28 \%$ relative to $389 \pm 60 \mathrm{~m} \mathrm{Wm}^{-2}$, which is the ACCMIP ensemble mean ozone RF in Table 1. While this estimate has reduced variability relative to the full ACCMIP ensemble ozone radiative forcing, it does not fully account for other sources of uncertainty, e.g., differences in radiative transfer models (Forster et al., 2011).

\section{Conclusions}

We have presented an evaluation of ACCMIP OLR from tropospheric ozone using TES ozone and LIRK data. We further explored the implication of this evaluation on ozone RF estimates. We find a significant correlation $R^{2}=0.59$ between $\left|\delta \mathrm{OLR}_{m}\right|$ and the absolute deviation from the ACCMIP ensemble ozone RF, $\triangle_{m}$. However, this correlation drops to $R^{2}=0.18$ if we only include models for which $|\delta \mathrm{OLR}|<100 \mathrm{~m} \mathrm{Wm}^{-2}$. Using this change in correlation as a basis for ensemble selection, we estimate the ACCMIP RF to be $394 \pm 42 \mathrm{~m} \mathrm{Wm}^{-2}$ (1 standard deviation), which is close to the ACCMIP full ensemble mean RF of Stevenson et al. (2013) but with about $30 \%$ less standard deviation. We note that our calculation used only 14 of the 16 models used by Stevenson et al. (2013). This result is in contrast to the lack of correlation across the full ACCMIP ensemble between present day tropospheric ozone bias and the change in ozone burden from preindustrial to present day reported by Young et al. (2013). However, our estimate does not account for bias associated with preindustrial emissions nor with others sources of uncertainty such as differences in the physical climate or radiative transfer algorithms. The results further suggest that any causal relationship between present day model OLR bias and model ozone RF could be model specific and not necessarily reflective of any general relationship between present day OLR and ozone RF.

We investigated the spatial patterns driving present-day bias in ACCMIP OLR from tropospheric ozone. These patterns were driven in the ACCMIP models by variations in the $\mathrm{SH}$ tropics and sub-tropics where the ensemble mean $\overline{\delta \mathrm{OLR}}_{j}$ reached $100 \mathrm{~m} \mathrm{Wm}^{-2}$ in some regions. Persistent patterns of $\delta \mathrm{OLR}_{m}^{j}$ were centered over the tropical Atlantic and over Southern Africa. While the importance of upper tropospheric ozone to ozone RF is known (Lacis et al., 1990;
Gauss et al., 2003), significant $\delta \mathrm{OLR}_{l}^{j, m}\left(>10 \mathrm{~m} \mathrm{Wm}^{-2}\right)$ could be attributed to ACCMIP ozone bias at pressures exceeding $600 \mathrm{hPa}$. While the modest low bias in $\delta \mathrm{OLR}_{m}^{j}$ in the NH can be attributed in part to a systematic TES retrieval overestimate, the ACCMIP SH low bias in $\delta \mathrm{OLR}_{m}^{j}$ is robust in light of the smaller TES tropical retrieval systematic errors.

Our results demonstrate a motivation for developing more sophisticated approaches that incorporate explicit statistical modeling of present day OLR bias from tropospheric ozone and ozone RF. Such approaches would permit a more rigorous means of weighting model ozone RF based upon their relationship to observations (Tebaldi et al., 2005; Berliner and Kim, 2008). There is considerable interest in using both data and an ensemble of climate models to understand historic change and probabilistically weight future projections (Knutti et al., 2002; Collins, 2007; Tebaldi and Knutti, 2007). There has been little to no application of these methodologies to chemistry-climate projections or the attribution of historic climate change to chemically active agents as has been done in detection and attribution studies for temperature (Hegerl et al., 1996; Santer et al., 2007; Huber and Knutti, 2012). There is also the potential of using advanced data assimilation techniques to attribute observed OLR to natural and anthropogenic emissions at finer spatial resolution (Bowman and Henze, 2012). The combination of these approaches with a process-based analysis (Eyring et al., 2005, 2006; Waugh and Eyring, 2008) can help test radiatively important processes against observations in a manner that can reduce our uncertainty in ozone RF and increase the reliability of future projections.

Acknowledgements. We thank the anonymous reviewers for their thoughtful comments and suggestions. The manuscript is greatly improved as a consequence.

This research was carried out at the Jet Propulsion Laboratory, California Institute of Technology, under a contract with NASA. The TES monthly ozone and IRK dataset was developed using techniques from the obs4MIP activity (http://obs4mips.llnl.gov:8080/ wiki/)

The National Center for Atmospheric Research (NCAR) is sponsored by the National Science Foundation.

KB and HW acknowledges the support of the NASA Aura ROSES program. KB also acknowledges some useful codes from Adetutu Aghedo and Rachel Hodos in the initial processing of TES data to netcdf files.

ACCMIP is organized under the auspices of Atmospheric Chemistry and Climate (AC\&C), a project of International Global Atmospheric Chemistry (IGAC) and Stratospheric Processes And their Role in Climate (SPARC) under the International GeosphereBiosphere Project (IGBP) and World Climate Research Program (WCRP).

The CESM project is supported by the National Science Foundation and the Office of Science (BER) of the US Department of Energy. 
The National Center for Atmospheric Research is operated by the University Corporation for Atmospheric Research under sponsorship of the National Science Foundation.

GZ acknowledges NIWA HPCF facility and funding from New Zealand Ministry of Science and Innovation.

The work of DB and PC was funded by the US Dept. of Energy (BER), performed under the auspices of LLNL under Contract DE-AC52-07NA27344, and used the supercomputing resources of NERSC under contract No. DE-AC02-05CH11231.

Ghan was supported by the US Department of Energy Office of Science Decadal and Regional Climate Prediction using Earth System Models (EaSM) program. The Pacific Northwest National Laboratory (PNNL) is operated for the DOE by Battelle Memorial Institute under contract DE-AC06-76RLO 1830.

W. J. Collins, G. A. Folberth, F. O'Connor and S. T. Rumbold were supported by the Joint DECC and Defra Integrated Climate Programme (GA01101).

VN and LWH acknowledge efforts of GFDL's Global Atmospheric Model Development Team in the development of the GFDL-AM3 and Modeling Services Group for assistance with data processing

The GEOSCCM work was supported by the NASA Modeling, Analysis and Prediction program, with computing resources provided by NASA's High-End Computing Program through the NASA Advanced Supercomputing Division.

The MIROC-CHEM calculations were performed on the NIES supercomputer system (NEC SX-8R), and supported by the Environment Research and Technology Development Fund (S-7)of the Ministry of the Environment, Japan.

The STOC-HadAM3 work was supported by cross UK research council grant NE/I008063/1 and used facilities provided by the UK's national high-performance computing service, HECToR, through Computational Modelling Services (CMS), part of the NERC National Centre for Atmospheric Science (NCAS).

The LMDz-OR-INCA simulations were done using computing ressources provided by the CCRT/GENCI computer center of the CEA.

The CICERO-OsloCTM2 simulations were done within the projects SLAC (Short Lived Atmospheric Components) and EarthClim funded by the Norwegian Research Council.

The MOCAGE simulations were supported by Météo-France and CNRS. Supercomputing time was provided by Météo-France/DSI supercomputing center.

DS and Y. H. Lee acknowledges support from the NASA MAP and ACMAP programs.

DP would like to thank the Canadian Foundation for Climate and Atmospheric Sciences for their long-running support of CMAM development.

Edited by: M. Dameris

\section{References}

Aghedo, A. M., Schultz, M. G., and Rast, S.: The influence of African air pollution on regional and global tropospheric ozone, Atmos. Chem. Phys., 7, 1193-1212, doi:10.5194/acp-7-11932007, 2007.

Aghedo, A. M., Bowman, K. W., Shindell, D. T., and Faluvegi, G.: The impact of orbital sampling, monthly averaging and vertical resolution on climate chemistry model evaluation with satellite observations, Atmos. Chem. Phys., 11, 6493-6514, doi:10.5194/acp-11-6493-2011, 2011a.

Aghedo, A. M., Bowman, K. W., Worden, H. M., Kulawik, S. S., Shindell, D. T., Lamarque, J. F., Faluvegi, G., Parrington, M., Jones, D. B. A., and Rast, S.: The vertical distribution of ozone instantaneous radiative forcing from satellite and chemistry climate models, J. Geophys. Res., 116, D01305, doi:10.1029/2010JD014243, 2011 b.

Arellano, A. F., Kasibhatla, P. S., Giglio, L., van der Werf, G. R., Randerson, J. T., and Collatz, G. J.: Time-dependent inversion estimates of global biomass-burning CO emissions using Measurement of Pollution in the Troposphere (MOPITT) measurements, J. Geophys. Res., 111, D09303, doi:10.1029/2005JD006613, 2006.

Beer, R.: TES on the Aura Mission: Scientific Objectives, Measurements, and Analysis Overview, IEEE Trans. Geosci. Remote Sens., 44, 1102-1105, 2006.

Berliner, L. M. and Kim, Y.: Bayesian Design and Analysis for Superensemble-Based Climate Forecasting, J. Climate, 21, 1891-1910, 2008.

Bowman, K. and Henze, D. K.: Attribution of direct ozone radiative forcing to spatially resolved emissions, Geophys. Res. Lett., 39, L22704, doi:10.1029/2012GL053274, 2012.

Bowman, K., Worden, J., Steck, T., Worden, H., Clough, S., and Rodgers, C.: Capturing time and vertical variability of tropospheric ozone: A study using TES nadir retrievals, J. Geophys. Res., 107, 4723, doi:10.1029/2002JD002150, 2002.

Bowman, K. W., Rodgers, C. D., Kulawik, S. S., Worden, J., Sarkissian, E., Osterman, G., Steck, T., Lou, M., Eldering, A., Shephard, M., Worden, H., Lampel, M., Clough, S., Brown, P., Rinsland, C., Gunson, M., and Beer, R.: Tropospheric Emission Spectrometer: Retrieval Method and Error Analysis, IEEE Trans. Geosci. Remote Sens., 44, 1297-1307, doi:10.1109/TGRS.2006.871234, 2006.

Bowman, K. W., Jones, D. B. A., Logan, J. A., Worden, H., Boersma, F., Chang, R., Kulawik, S., Osterman, G., Hamer, P., and Worden, J.: The zonal structure of tropical $\mathrm{O}_{3}$ and $\mathrm{CO}$ as observed by the Tropospheric Emission Spectrometer in November 2004 Part 2: Impact of surface emissions on $\mathrm{O}_{3}$ and its precursors, Atmos. Chem. Phys., 9, 3563-3582, doi:10.5194/acp-93563-2009, 2009.

Boxe, C. S., Worden, J. R., Bowman, K. W., Kulawik, S. S., Neu, J. L., Ford, W. C., Osterman, G. B., Herman, R. L., Eldering, A., Tarasick, D. W., Thompson, A. M., Doughty, D. C., Hoffmann, M. R., and Oltmans, S. J.: Validation of northern latitude Tropospheric Emission Spectrometer stare ozone profiles with ARC-IONS sondes during ARCTAS: sensitivity, bias and error analysis, Atmos. Chem. Phys., 10, 9901-9914, doi:10.5194/acp10-9901-2010, 2010.

Chandra, S., Ziemke, J. R., Duncan, B. N., Diehl, T. L., Livesey, N. J., and Froidevaux, L.: Effects of the 2006 El Niño on tro- 
pospheric ozone and carbon monoxide: implications for dynamics and biomass burning, Atmos. Chem. Phys., 9, 4239-4249, doi:10.5194/acp-9-4239-2009, 2009.

Chatfield, R. B. and Delany, A.: Convection links biomass burning to increased tropical ozone: However, models will tend to overpredict $\mathrm{O}_{3}$, J. Geophys. Res.-Atmos., 95, 18473-18488, 1990.

Chatfield, R. B., Guo, Z., Sachse, G. W., Blake, D. R., and Blake, N. J.: The subtropical global plume in the Pacific Exploratory Mission-Tropics A (PEM-Tropics A), PEM-Tropics B, and the Global Atmospheric Sampling Program (GASP): How tropical emissions affect the remote Pacific, J. Geophys. Res., 107, 4278, doi:10.1029/2001JD000497, 2002.

Clain, G., Baray, J. L., Delmas, R., Diab, R., Leclair de Bellevue, J., Keckhut, P., Posny, F., Metzger, J. M., and Cammas, J. P.: Tropospheric ozone climatology at two Southern Hemisphere tropical/subtropical sites, (Reunion Island and Irene, South Africa) from ozonesondes, LIDAR, and in situ aircraft measurements, Atmos. Chem. Phys., 9, 1723-1734, doi:10.5194/acp-9-17232009, 2009.

Clough, S. and Iacono, M.: Line-by-line Calculation of atmospheric fluxes and cooling rates.2. application to carbon-dioxide, ozone, methane, nitrous-oxide and the halocarbons, J. Geophys. Res.Atmos., 100, 16519-16535, 1995.

Clough, S., Shepard, M., Worden, J. R., Brown, P. D., Worden, H. M., Lou, M., Rodgers, C., Rinsland, C., Goldman, A., Brown, L., Eldering, A., Kulawik, S. S., Cady-Pereira, K., Osterman, G., and Beer, R.: Forward Model and Jacobians for Tropospheric Emission Spectrometer Retrievals, IEEE Trans. Geosci. Remote Sens., 44, 1308-1323, 2006.

Collins, M.: Ensembles and probabilities: a new era in the prediction of climate change, Phil. Trans. R. Soc. A, 365, 1957-1970, doi:10.1098/rsta.2007.2068, 2007.

Collins, W. J., Sitch, S., and Boucher, O.: How vegetation impacts affect climate metrics for ozone precursors, J. Geophys. Res., 115, doi:10.1029/2010JD014187, 2010.

Connor, T. C., Shephard, M. W., Payne, V. H., Cady-Pereira, K. E., Kulawik, S. S., Luo, M., Osterman, G., and Lampel, M.: Long-term stability of TES satellite radiance measurements, Atmos. Meas. Tech., 4, 1481-1490, doi:10.5194/amt-4-1481-2011, 2011.

Edwards, D. P., Emmons, L. K., Gille, J. C., Chu, A., Attié, J.-L., Giglio, L., Wood, S. W., Haywood, J., Deeter, M. N., Massie, S. T., Ziskin, D. C., and Drummond, J. R.: Satellite-observed pollution from Southern Hemisphere biomass burning, J. Geophys. Res.-Atmos., D14312, doi:10.1029/2005JD006655, 2006.

Edwards, J. M. and Slingo, A.: Studies with a flexible new radiation code. I: Choosing a configuration for a largescale model, Q. J. Roy. Meteorol. Soc., 122, 689-719, doi:10.1002/qj.49712253107, 1996.

Eldering, A., Kulawik, S. S., Worden, J., Bowman, K., and Osterman, G.: Implementation of cloud retrievals for TES atmospheric retrievals: 2. Characterization of cloud top pressure and effective optical depth retrievals, J. Geophys. Res., 113, D16S37, doi:10.1029/2007JD008858, 2008.

Eyring, V., Harris, N., Rex, M., Sheperd, T., Fahey, D., Amanatidis, G., Austin, J., Chipperfield, M., Dameris, M., De, P., Forster, F., Gettelman, A., Graf, H., Nagashima, T., Newman, P., Pawson, S., Prather, M. J., Pyle, J. A., Salawitch, J., Santer, B., and Waugh, D. W.: A Strategy for Process-Oriented Validation of Coupled
Chemistry-Climate Models, B. Am. Meteorol. Soc., 86, 11171133, doi:10.1175/BAMS-86-8-1117, 2005.

Eyring, V., Butchart, N., Waugh, D. W., Akiyoshi, H., Austin, J., Bekki, S., Bodeker, G. E., Boville, B. A., Brühl, C., Chipperfield, M. P., Cordero, E., Dameris, M., Deushi, M., Fioletov, V. E., Frith, S. M., Garcia, R. R., Gettelman, A., Giorgetta, M. A., Grewe, V., Jourdain, L., Kinnison, D. E., Mancini, E., Manzini, E., Marchand, M., Marsh, D. R., Nagashima, T., Newman, P. A., Nielsen, J. E., Pawson, S., Pitari, G., Plummer, D. A., Rozanov, E., Schraner, M., Shepherd, T. G., Shibata, K., Stolarski, R. S., Struthers, H., Tian, W., and Yoshiki, M.: Assessment of temperature, trace species, and ozone in chemistry-climate model simulations of the recent past, J. Geophys. Res., 111, D22308, doi:10.1029/2006JD007327, 2006.

Fasullo, J. T. and Trenberth, K. E.: A Less Cloudy Future: The Role of Subtropical Subsidence in Climate Sensitivity, Science, 338, 792-794, 2012.

Fels, S. B., Mahlman, J. D., Schwarzkopf, M. D., and Sinclair, R. W.: Stratospheric Sensitivity to Perturbations in Ozone and Carbon Dioxide: Radiative and Dynamical Response, Journal of the Atmospheric Sciences, 37, 2265-2297, doi:10.1175/15200469(1980)037<2265:SSTPIO>2.0.CO;2, 1980.

Forster, P., Ramaswamy, V., Artaxo, P., Berntsen, T., Betts, R., Fahey, D., Haywood, J., Lean, J., Lowe, D., Myhre, G., Nganga, J., Prinn, R., Raga, G., Schulz, M., and Dorland, R. V.: Climate Change 2007: The Physical Science Basis. Contribution of Working Group I to the Fourth Assessment Report of the Intergovernmental Panel on Climate Change, chap. Changes in Atmospheric Constituents and in Radiative Forcing, 131-217, Cambridge University Press, 2007.

Forster, P. M., Fomichev, V. I., Rozanov, E., Cagnazzo, C., Jonsson, A. I., Langematz, U., Fomin, B., Iacono, M. J., Mayer, B., Mlawer, E., Myhre, G., Portmann, R. W., Akiyoshi, H., Falaleeva, V., Gillett, N., Karpechko, A., Li, J., Lemennais, P., Morgenstern, O., Oberländer, S., Sigmond, M., and Shibata, K.: Evaluation of radiation scheme performance within chemistry climate models, J. Geophys. Res., 116, doi:10.1029/2010JD015361, , 2011.

Forster, P. M. F., Freckleton, R. S., and Shine, K. P.: On aspects of the concept of radiative forcing, Clim. Dynam., 13, 547-560, doi:10.1007/s003820050182, 1997.

Garstang, M., Tyson, P. D., Swap, R., Edwards, M., Kallberg, P., and Lindesay, J. A.: Horizontal and vertical transport of air over southern Africa, J. Geophys. Res.-Atmos., 101, 23721-23736, 1996.

Gauss, M., Myhre, G., Pitari, G., Prather, M. J., Isaksen, I. S. A., Berntsen, T. K., Brasseur, G. P., Dentener, F. J., Derwent, R. G., Hauglustaine, D. A., Horowitz, L. W., Jacob, D. J., Johnson, M., Law, K. S., Mickley, L. J., Muller, J.-F., Plantevin, P.-H., Pyle, J. A., Rogers, H. L., Stevenson, D. S., Sundet, J. K., van Weele, M., and Wild, O.: Radiative forcing in the 21 st century due to ozone changes in the troposphere and the lower stratosphere, J. Geophys. Res., 108, 4292, doi:10.1029/2002JD002624, 2003.

Hansen, J., Sato, M., and Ruedy, R.: Radiative Forcing and climate response, J. Geophys. Res., 102, 6831-6864, 1997.

Hansen, J., Sato, M., Kharecha, P., Russell, G., Lea, D. W., and Siddal, M.: Climate change and trace gases, Phil. Trans. R. Soc. A, 365, 1925-1954, doi:10.1098/rsta.2007.2052, 2007. 
Hegerl, G. C., von Storch, H., Hasselmann, K., Santer, B. D., Cubasch, U., and Jones, P. D.: Detecting Greenhouse-GasInduced Climate Change with an Optimal Fingerprint Method, J. Climate, 9, 2281-2306, 1996.

Huber, M. and Knutti, R.: Anthropogenic and natural warming inferred from changes in Earth's energy balance, Nature Geosci, 5, 31-36, doi:10.1038/ngeo1327, 2012.

Jacob, D., Heikes, B. G., Fan, S.-M., Logan, J. A., Mauzerall, D. L., Bradshaw, J. D., Singh, H. B., Gregory, G. L., Talbot, R. W., Blake, D. R., and Sachse, G. W.: Origin of ozone and $\mathrm{NO}_{\mathrm{x}}$ in the tropical troposphere: A photochemical analysis of aircraft observations over the South Atlantic basin, J. Geophys. Res.-Atmos., 101, 24235-24250, doi:10.1029/96JD00336, 1996.

Jenkins, G. S. and Ryu, J.-H.: Linking horizontal and vertical transports of biomass fire emissionsto the tropical Atlantic ozone paradox during the Northern Hemisphere winter season: climatology, Atmos. Chem. Phys., 4, 449-469, doi:10.5194/acp-4449-2004, 2004.

Jones, D. B. A., Bowman, K. W., Logan, J. A., Heald, C. L., Liu, J., Luo, M., Worden, J., and Drummond, J.: The zonal structure of tropical $\mathrm{O}_{3}$ and $\mathrm{CO}$ as observed by the Tropospheric Emission Spectrometer in November 2004 -Part 1: Inverse modeling of CO emissions, Atmos. Chem. Phys., 9, 3547-3562, doi:10.5194/acp-9-3547-2009, 2009.

Knutti, R. and Hegerl, G. C.: The equilibrium sensitivity of the Earth's temperature to radiation changes, Nature Geosci., 1, 735743, 2008.

Knutti, R., Stocker, T. F., Joos, F., and Plattner, G.-K.: Constraints on radiative forcing and future climate change from observations and climate model ensembles, Nature, 416, 719-722, 2002.

Kulawik, S. S., Worden, J., Eldering, A., Bowman, K., Gunson, M., Osterman, G. B., Zhang, L., Clough, S. A., Shephard, M. W., and Beer, R.: Implementation of cloud retrievals for Tropospheric Emission Spectrometer (TES) atmospheric retrievals: part 1. Description and characterization of errors on trace gas retrievals, J. Geophys. Res., 111, D24204, doi:10.1029/2005JD006733, 2006.

Lacis, A. A., Wuebbles, D. J., and Logan, J. A.: Radiative Forcing of Climate by Changes in the Vertical Distribution of Ozone, J. Geophys. Res., 95, 9971-9981, doi:10.1029/JD095iD07p09971, 1990.

Lamarque, J.-F., Bond, T. C., Eyring, V., Granier, C., Heil, A., Klimont, Z., Lee, D., Liousse, C., Mieville, A., Owen, B., Schultz, M. G., Shindell, D., Smith, S. J., Stehfest, E., Van Aardenne, J., Cooper, O. R., Kainuma, M., Mahowald, N., McConnell, J. R., Naik, V., Riahi, K., and van Vuuren, D. P.: Historical (1850-2000) gridded anthropogenic and biomass burning emissions of reactive gases and aerosols: methodology and application, Atmos. Chem. Phys., 10, 7017-7039, doi:10.5194/acp10-7017-2010, 2010.

Lamarque, J. F., Shindell, D. T., Josse, B., Young, P. J., Cionni, I., Eyring, V., Bergmann, D., Cameron-Smith, P., Collins, W. J., Doherty, R., Dalsoren, S., Faluvegi, G., Folberth, G., Ghan, S. J., Horowitz, L. W., Lee, Y. H., MacKenzie, I. A., Nagashima, T., Naik, V., Plummer, D., Righi, M., Rumbold, S. T., Schulz, M., Skeie, R. B., Stevenson, D. S., Strode, S., Sudo, K., Szopa, S., Voulgarakis, A., and Zeng, G.: The Atmospheric Chemistry and Climate Model Intercomparison Project (ACCMIP): overview and description of models, simulations and climate diagnostics, Geosci. Model Dev., 6, 179-206, doi:10.5194/gmd-6-179-2013,
2013.

Levy, II., H., Schwarzkopf, M. D., Horowitz, L., Ramaswamy, V., and Findell, K. L.: Strong sensitivity of late 21 st century climate to projected changes in short-lived air pollutants, J. Geophys. Res., 113, D06102, doi:10.1029/2007JD009176, 2008.

Li, Q., Jacob, D. J., Logan, J. A., Bey, I., Yantosca, R. M., Liu, H., Martin, R. V., Fiore, A. M., Field, B. D., Duncan, B. N., and Thouret, V.: A tropospheric ozone maximum over the Middle East, Geophys. Res. Lett., 28, 3235-3238, doi:10.1029/2001GL013134, 2001.

Liu, J., Logan, J., Jones, D. B. A., Livesey, N. J., Megretskaia, I., Carouge, C., and Nedelec, P.: Analysis of CO in the tropical troposphere using Aura satellite data and the GEOS-Chem model: insights into transport characteristics of the GEOS meteorological products, Atmos. Chem. Phys., 10, 12207-12232, doi:10.5194/acp-10-12207-2010, 2010.

Liu, J. J., Jones, D. B. A., Worden, J. R., Noone, D., Parrington, M., and Kar, J.: Analysis of the summertime buildup of tropospheric ozone abundances over the Middle East and North Africa as observed by the Tropospheric Emission Spectrometer instrument, J. Geophys. Res., 114, D05304, doi:10.1029/2008JD010993, 2009.

Molod, A., Takacs, L., Suarez, M., Bacmeister, J., Song, I., and Eichmann, A.: The GEOS-5 Atmospheric General Circulation Model: Mean Climate and Development from MERRA to Fortuna, Tech. Rep. 28, Goddard Space Flight Center, 2012.

Naik, V., Mauzerall, D., Horowitz, L., Schwarzkopf, M. D., Ramaswamy, V., and Oppenheimer, M.: Net radiative forcing due to changes in regional emissions of tropospheric ozone precursors, J. Geophys. Res.-Atmos., 110, D24306, doi:10.1029/2005JD005908, 2005.

Nassar, R., Logan, J., Worden, H., Megretskaia, I. A., Bowman, K., Osterman, G., Thompson, A. M., Tarasick, D. W., Austin, S., Claude, H., Dubey, M. K., Hocking, W. K., Johnson, B. J., Joseph, E., Merrill, J., Morris, G. A., Newchurch, M., Oltmans, S. J., Posny, F., and Schmidlin, F.: Validation of Tropospheric Emission Spectrometer (TES) Nadir Ozone Profiles Using Ozonesonde Measurements, J. Geophys. Res, 113, D15S17, doi:10.1029/2007JD008819, 2008.

Nassar, R., Logan, J. A., Megretskaia, I. A., Murray, L. T., Zhang, L., and Jones, D. B. A.: Analysis of tropical tropospheric ozone, carbon monoxide, and water vapor during the 2006 El Niño using TES observations and the GEOS-Chem model, J. Geophys. Res., 114, D17304, doi:10.1029/2009JD011760, 2009.

Osterman, G., Kulawik, S., Worden, H., Richards, N., Fisher, B., Eldering, A., Shephard, M., Froidevaux, L., Labow, G., Luo, M., Herman, R., and Bowman, K.: Validation of Tropospheric Emission Spectrometer (TES) Measurements of the Total, Stratospheric and Tropospheric Column Abundance of Ozone, J. Geophys. Res., 113, D15S16, doi:10.1029/2007JD008801, 2008.

Ramanathan, V. and $\mathrm{Xu}, \mathrm{Y}$.: The Copenhagen Accord for limiting global warming: Criteria, constraints, and available avenues, Proc. Natl. Acad. Sci., 107, 8055-8062, 2010.

Richards, N. A. D., Osterman, G. B., Browell, E. V., Hair, J. W., Avery, M., and Li, Q.: Validation of Tropospheric Emission Spectrometer ozone profiles with aircraft observations during the Intercontinental Chemical Transport Experiment-B, J. Geophys. Res., 113, D16S29, doi:10.1029/2007JD008815, 2008.

Santer, B. D., Mears, C., Wentzc, F. J., Taylora, K. E., Glecklera, P. J., Wigleyd, T. M. L., Barnette, T. P., Boylea, J. S., andN. 
P. Gillettg, W. B., Kleina, S. A., Meehld, G. A., Nozawah, T., Piercee, D. W., Stotti, P. A., Washingtond, W. M., and Wehner, M. F.: Identification of human-induced changes in atmospheric moisture content, PNAS, 104, 15248-15253, 2007.

Sauvage, B., Martin, R. V., van Donkelaar, A., and Ziemke, J. R.: Quantification of the factors controlling tropical tropospheric ozone and the South Atlantic maximum, J. Geophys. Res., 112, D11309, doi:10.1029/2006JD008008, 2007.

Shephard, M. W., Worden, H. M., Cady-Pereira, K. E., Lampel, M., Luo, M., Bowman, K. W., Sarkissian, E., Beer, R., Rider, D. M., Tobin, D. C., Revercomb, H. E., Fisher, B. M., Tremblay, D., Clough, S. A., Osterman, G. B., and Gunson, M.: Tropospheric Emission Spectrometer Spectral Radiance Comparisons, J. Geophys. Res., 113, D15S05, doi:10.1029/2007JD008856, 2008.

Shindell, D. and Faluvegi, G.: Climate response to regional radiative forcing during the twentieth century, Nature Geosci., 2, 294-300, doi:10.1038/ngeo473, 2009.

Shindell, D. and Lamarque, J.: Atmospheric Chemistry and Climate Model Intercomparison Project (ACC-MIP), IGACtivities Newsletter, 41, 2009.

Shindell, D. T., Faluvegi, G., Bell, N., and Schmidt, G. A.: An emissions-based view of climate forcing by methane and tropospheric ozone, Geophys. Res. Lett., 32, L04803, doi:10.1029/2004GL021900, 2005.

Shindell, D. T., Hiram Levy II, Schwarzkopf, M. D., Horowitz, L. W., Lamarque, J.-F., and Faluvegi, G.: Multimodel projections of climate change from short-lived emissions due to human activities, J. Geophys. Res., 113, D11109, doi:10.1029/2007JD009152, 2008.

Shindell, D. T., Faluvegi, G., Koch, D. M., Schmidt, G. A., Unger, N., and Bauer, S. E.: Improved Attribution of Climate Forcing to Emissions, Science, 326, 716-718, 2009.

Shindell, D. T., Pechony, O., Voulgarakis, A., Faluvegi, G., Nazarenko, L., Lamarque, J.-F., Bowman, K., Milly, G., Kovari, B., Ruedy, R., and Schmidt, G. A.: Interactive ozone and methane chemistry in GISS-E2 historical and future climate simulations, Atmos. Chem. Phys., 13, 2653-2689, doi:10.5194/acp-13-26532013, 2013.

Sinha, P., Jaeglé, L., Hobbs, P. V., and Liang, Q.: Transport of biomass burning emissions from southern Africa, J. Geophys. Res., 109, D20204, doi:10.1029/2004JD005044, 2004.

Sitch, S., Cox, P. M., Collins, W. J., and Huntingford, C.: Indirect radiative forcing of climate change through ozone effects on the land-carbon sink, Nature, 448, 791-794, doi:10.1038/nature06059, 2007.

Skeie, R. B., Berntsen, T. K., Myhre, G., Tanaka, K., Kvalevag, M. M., and Hoyle, C. R.: Anthropogenic radiative forcing time series from pre-industrial times until 2010, Atmos. Chem. Phys., 11, 11827-11857, doi:10.5194/acp-11-11827-2011, 2011.

Stevenson, D. S., Dentener, F. J., Schultz, M. G., Ellingsen, K., van Noije, T. P. C., Wild, O., Zeng, G., Amann, M., Atherton, C. S., Bell, N., Bergmann, D. J., Bey, I., Butler, T., Cofala, J., Collins, W. J., Derwent, R. G., Doherty, R. M., Drevet, J., Eskes, H. J., Fiore, A. M., Gauss, M., Hauglustaine, D. A., Horowitz, L. W., Isaksen, I. S. A., Krol, M. C., Lamarque, J.-F., Lawrence, M. G., Montanaro, V., Müller, J.-F., Pitari, G., Prather, M. J., Pyle, J. A., Rast, S., Rodriguez, J. M., Sanderson, M. G., Savage, N. H., Shindell, D. T., Strahan, S. E., Sudo, K., and Szopa, S.: Multimodel ensemble simulations of present-day and near-future tropospheric ozone, J. Geophys. Res., 111, D08301, doi:10.1029/2005JD006338, 2006.

Stevenson, D. S., Young, P. J., Naik, V., Lamarque, J.-F., Shindell, D. T., Voulgarakis, A., Skeie, R. B., Dalsoren, S. B., Myhre, G., Berntsen, T. K., Folberth, G. A., Rumbold, S. T., Collins, W. J., MacKenzie, I. A., Doherty, R. M., Zeng, G., van Noije, T. P. C., Strunk, A., Bergmann, D., Cameron-Smith, P., Plummer, D. A., Strode, S. A., Horowitz, L., Lee, Y. H., Szopa, S., Sudo, K., Nagashima, T., Josse, B., Cionni, I., Righi, M., Eyring, V., Conley, A., Bowman, K. W., Wild, O., and Archibald, A.: Tropospheric ozone changes, radiative forcing and attribution to emissions in the Atmospheric Chemistry and Climate Model Intercomparison Project (ACCMIP), Atmos. Chem. Phys., 13, 3063-3085, doi:10.5194/acp-13-3063-2013, 2013.

Taylor, K. E., Stouffer, R. J., and Meehl, G. A.: An Overview of CMIP5 and the Experiment Design, B. Am. Meteor. Soc., 93, 485-498, doi:10.1175/BAMS-D-11-00094.1, 2011.

Tebaldi, C. and Knutti, R.: The use of the multi-model ensemble in probabilistic climate projections, Phil. Trans. R. Soc. A, 365, 2053-2075, doi:10.1098/rsta.2007.2076, 2007.

Tebaldi, C., Smith, R. L., Nychka, D., and Mearns, L. O.: Quantifying Uncertainty in Projections of Regional Climate Change: A Bayesian Approach to the Analysis of Multimodel Ensembles, J. Climate, 18, 1524-1540, 2005.

van Vuuren, D., Edmonds, J., Kainuma, M., Riahi, K., Thomson, A., Hibbard, K., Hurtt, G., Kram, T., Krey, V., Lamarque, J.F., Masui, T., Meinshausen, M., Nakicenovic, N., Smith, S., and Rose, S.: The representative concentration pathways: an overview, Climatic Change, 109, 5-31, doi:10.1007/s10584-0110148-z, 2011.

van Vuuren, D. P., Weyant, J., and de la Chesnaye, F.: Multi-gas scenarios to stabilize radiative forcing, Energy Econom., 28, 102120, 2006.

Voulgarakis, A., Naik, V., Lamarque, J.-F., Shindell, D. T., Young, P. J., Prather, M. J., Wild, O., Field, R. D., Bergmann, D., CameronSmith, P., Cionni, I., Collins, W. J., Dalsøren, S. B., Doherty, R. M., Eyring, V., Faluvegi, G., Folberth, G. A., Horowitz, L. W., Josse, B., MacKenzie, I. A., Nagashima, T., Plummer, D. A., Righi, M., Rumbold, S. T., Stevenson, D. S., Strode, S. A., Sudo, K., Szopa, S., and Zeng, G.: Analysis of present day and future $\mathrm{OH}$ and methane lifetime in the ACCMIP simulations, Atmos. Chem. Phys., 13, 2563-2587, doi:10.5194/acp-13-25632013, 2013.

Wallack, J. S. and Ramanathan, V.: The Other Climate Changers: Why Black Carbon and Ozone Also Matter, Foreign Affairs, available online at: http://www.foreignaffairs.com/articles/ 65238/jessica-seddon-wallack-and-veerabhadran-ramanathan/ the-other-climate-changers (last access: 10 April 2013), 2009.

Wang, Y. H. and Jacob, D. J.: Anthropogenic forcing on tropospheric ozone and $\mathrm{OH}$ since preindustrial times, J. Geophys. Res.-Atmos., 103, 31123-31135, 1998.

Waugh, D. W. and Eyring, V.: Quantitative performance metrics for stratospheric-resolving chemistry-climate models, Atmos. Chem. Phys., 8, 5699-5713, doi:10.5194/acp-8-5699-2008, 2008.

West, J. J., Fiore, A. M., Horowitz, L. W., and Mauzerall, D. L.: Global health benefits of mitigating ozone pollution with methane emission controls, Proceedings of the National Academy of Sciences of the United States of America, 103, 
3988-3993, doi:10.1073/pnas.0600201103, 2006.

West, J. J., Fiore, A. M., Naik, V., Horowitz, L. W., Schwarzkopf, M. D., and Mauzerall, D. L.: Ozone air quality and radiative forcing consequences of changes in ozone precursor emissions, Geophys. Res. Lett., 34, L06806, doi:10.1029/2006GL029173, 2007.

Worden, H. M., Logan, J. A., Worden, J. R., Beer, R., Bowman, K., Clough, S. A., Eldering, A., Fisher, B. M., Gunson, M. R., Herman, R. L., Kulawik, S. S., Lampel, M. C., Luo, M., Megretskaia, I. A., Osterman, G. B., and Shephard, M.: Comparisons of Tropospheric Emission Spectrometer (TES) ozone profiles to ozonesondes: methods and initial results, J. Geophys. Res.Atmos., 112, D03309, doi:10.1029/2006JD007258, 2007.

Worden, H. M., Bowman, K. W., Worden, J. R., Eldering, A., and Beer, R.: Satellite measurements of the clear-sky greenhouse effect from tropospheric ozone, Nature Geosci., doi:10.1038/ngeo182, 2008.

Worden, H. M., Bowman, K. W., Kulawik, S. S., and Aghedo, A. M.: Sensitivity of outgoing longwave radiative flux to the global vertical distribution of ozone characterized by instantaneous radiative kernels from Aura-TES, J. Geophys. Res., 116, D14115, doi:10.1029/2010JD015101, 2011.
Worden, J., Kulawik, S. S., Shephard, M. W., Clough, S. A., Worden, H., Bowman, K., and Goldman, A.: Predicted errors of tropospheric emission spectrometer nadir retrievals from spectral window selection, J. Geophys. Res., 109, D09308, doi:10.1029/2004JD004522, 2004.

Young, P. J., Archibald, A. T., Bowman, K. W., Lamarque, J. F., Naik, V., Stevenson, D. S., Tilmes, S., Voulgarakis, A., Wild, O., Bergmann, D., Cameron-Smith, P., Cionni, I., Collins, W. J., Dalsøren, S. B., Doherty, R. M., Eyring, V., Faluvegi, G., Horowitz, L. W., Josse, B., Lee, Y. H., MacKenzie, I. A., Nagashima, T., Plummer, D. A., Righi, M., Rumbold, S. T., Skeie, R. B., Shindell, D. T., Strode, S. A., Sudo, K., Szopa, S., and Zeng, G.: Pre-industrial to end 21st century projections of tropospheric ozone from the Atmospheric Chemistry and Climate Model Intercomparison Project (ACCMIP), Atmos. Chem. Phys., 13, 2063-2090, doi:10.5194/acp-13-2063-2013, 2013. 